\title{
Urinary Catheter Coating Modifications: The Race against Catheter-Associated Infections
}

\author{
Marissa J. Andersen and Ana L. Flores-Mireles * \\ Department of Biological Sciences, University of Notre Dame, Notre Dame, IN 46556, USA; mander40@nd.edu \\ * Correspondence: afloresm@nd.edu; Tel.: +574-631-4964
}

Received: 14 November 2019; Accepted: 26 December 2019; Published: 29 December 2019

\begin{abstract}
Urinary catheters are common medical devices, whose main function is to drain the bladder. Although they improve patients' quality of life, catheter placement predisposes the patient to develop a catheter-associated urinary tract infection (CAUTI). The catheter is used by pathogens as a platform for colonization and biofilm formation, leading to bacteriuria and increasing the risk of developing secondary bloodstream infections. In an effort to prevent microbial colonization, several catheter modifications have been made ranging from introduction of antimicrobial compounds to antifouling coatings. In this review, we discuss the effectiveness of different coatings in preventing catheter colonization in vitro and in vivo, the challenges in fighting CAUTIs, and novel approaches targeting host-catheter-microbe interactions.
\end{abstract}

Keywords: CAUTI; antimicrobial compounds; coatings; urinary catheters; microbial; surface modifications; biofilm

\section{Introduction}

The use of modern medical devices has revolutionized medical treatments, helping and improving quality of life for people with chronic and lifestyle diseases. Paradoxically, although these devices are successful in achieving their purpose, they often predispose the patient to infections. Indwelling urinary catheters are one of the most frequently used invasive medical devices [1-4]. The function of urinary catheters is to safely drain the urine from the bladder for short- or long-periods of time [5-7]. It is estimated that 100 million urinary catheters are sold worldwide each year [2] and more than 30 million are used annually in the United States [2,8,9]. This is reflected by the fact that that catheterization rates remain high at $20 \%$ in non-intensive care units (ICUs) and $61 \%$ in the ICU [10,11]. They are commonly used in patients that are comatose, incontinent, have neurogenic bladder, spinal cord injury, urine flow obstruction (enlarged prostate), or acute urinary retention. Urinary catheters are also common in patients that are anesthetized or sedated that will be undergoing surgical procedures including urogenital surgeries, cesarean sections, hysterectomies, laparoscopy, orthopedic procedures, etc. [12-15].

Unfortunately, hospitalized patients are at risk of development of catheter-associated bacteriuria just by placement of the urinary catheter, increasing the risk 3\%-6\% per day that the catheter is in place [16]. By 7-10 days of catheterization, $50 \%$ of hospitalized patients will have developed an infection. Catheter-associated urinary tract infections (CAUTIs) are a major threat to public health since they are the most common hospital-acquired infection worldwide, accounting for $40 \%$ of them, and leading to bloodstream infections with $30 \%$ mortality $[17,18]$. Great efforts have been made to prevent and manage CAUTI [12], a few of those strategies includes reducing usage and minimizing catheter dwell time [13,19]. These prevention methods appear to reduce incidence of CAUTI [13]. However, despite these preventive efforts, management of CAUTI is difficult since the microbial pathogens: (1) are able to form biofilms (microbial communities embedded in a self-produced polymeric matrix) 
on the surface of the catheter, protecting themselves against both antibiotics and the patient's immune system [20]; and (2) are becoming resistant to antibiotics [6,7,20-25].

Ongoing efforts to control CAUTI have been focused in preventing microbial colonization and biofilm formation by coating the surface of the catheter with bactericidal molecules (primarily focused on antimicrobials) or anti-fouling formulations (prevention of microbial attachment) $[15,24,26]$. Here we will review and contrast the efficiency of the different coatings in vitro, in animal models of CAUTI, and clinical trials. Furthermore, we will discuss the current challenges, the role of the host response to urinary catheterization, and new strategies based on the host-catheter-microbe interactions.

\section{Indwelling Urinary Catheter Materials}

Several materials have been used to develop standard urinary catheters including silicone (polydimethylsiloxane (PDMS)), latex, polyvinyl chloride (PVC), plastic, siliconized latex, silicone elastomers, polytetrafluoroethylene (PTFE)-coated latex, hydrogel-coated latex, and hydrogel- and hydrophilic polymer-coated latex $[27,28]$. The catheter material selection is based on the requirements of the patient. For example, silicone material will be used in those patients with latex allergies and those patients that present latex cytotoxicity [29]. Silicone catheters are also preferred over latex for their superior non-allergenic and flow properties as well as their resistance to kinking [5,30]. Additionally, the Center for Disease Control and Prevention (CDC) recommends silicone over other catheter materials for patients with frequent obstruction [12]. The CDC also recommends to those patients that require intermittent catheterization to use hydrophilic catheters over standard catheters to reduce urethral micro trauma [12,31].

Despite the variety of materials, urinary pathogens are still able to colonize the catheter and cause infections. To prevent microbial colonization and biofilm formation, urinary catheter materials have been modified by adding anti-fouling or bactericidal coatings [32]. An ideal coating agent should possess high anti-biofilm/antimicrobial efficacy and be easily and economically conjugated to the catheter surface [33]. On top of this, it needs to be biocompatible and not cause an increase in patient discomfort [15]. Below we will discuss the different surface modifications and their efficacy.

\section{Approaches to Restriction of CAUTI by Inhibition of Microbial Adhesion, Biofilm Formation, and Growth with no Killing Activity}

Anti-fouling modifications do not harm the microbes, they simply repel them thus, preventing establishment in the bladder or on the catheter and formation of biofilms. Polymer modifications make up a large section of research regarding antifouling properties of surfaces [15]. For catheter coating research, catheter materials can have antifouling properties themselves and/or serve as a scaffold for impregnation or attachment of biocidal molecules. There are several anti-fouling catheters including those coated with hydrogels (most popular) [27,28], poly(tetrafluoroethylene) [34-38], polyzwitterions [39-41], and poly(ethylene glycol) [42-46]. Furthermore, surface topography modification [47-50] and enzymes-immobilized coatings [51-58] have been explored for prevention of microbial colonization and biofilm formation. These polymers and modifications are discussed in detail in this section.

\subsection{Hydrogel}

Hydrogels are a group of insoluble, swellable, hydrophilic polymers. When fully swollen they are composed of a significant amount of water (up to 99\%) but also display solid-like properties, which provide desirable characteristics such as increased mechanical strength, all properties ideal for catheter materials [59]. Swelling of hydrogels forms a hydration layer on the catheter surface, which increases hydrophilicity and establishes a barrier to inhibit nonspecific protein adsorption. While the hydrophilicity of the coating is believed to be its antifouling mechanism, in practice the efficacy of the catheters have varied. For example, a clinical trial of males with an average catheterization length of 2.2 days, compared three types of catheters: (1) siliconized latex, (2) pure silicone, and 
(3) hydrogel-coated silicone. The results showed that pure silicone had the lowest urethral inflammation by immune cell count and fully resisted encrustation while hydrogel catheters successfully reduced encrustation of the catheter [27,60]. Contrary to the previous study, a separate clinical trial of 226 patients comparing hydrogel-coated and silicone-coated catheters showed no measured difference between the two groups in preventing incidence of nosocomial CAUTIs [61]. Furthermore, in an in vitro assay, hydrogel catheters were tested against Proteus mirabilis growth and encrustation of the catheter, showing that the hydrogel coating actually increased the rate of catheter blockage [39].

\subsection{Poly(Tetralfouroethalene) (PTFE) Coating}

PTFE-coated catheters, also known as Teflon-coated catheters, are commercially available from Bard Medical. Teflon has excellent non-stick properties via a low coefficient of friction, making it an optimal candidate for resisting bacterial colonization [34]; however, despite their desirable properties clinical data have shown that other coatings are better at preventing blockage and biofilm formation. For example, a clinical trial looking at the difference in blockage between (1) commercially available silicone, (2) silicone-coated, (3) teflon-coated, and (4) latex catheters that were placed for 14 days showed the silicone catheter had significantly lower blockage over latex and teflon-coated catheters [35]. In another test, teflon-coated catheters were compared with hydrogel-coated and silicon catheters for their ability to prevent bacterial adherence and reduce mucosal irritation. This study showed that hydrogel was superior over the teflon-coated or silicone catheters, since it had the lowest degree of bacterial adherence and mucosal irritation among these products [36]. Interestingly, in some studies teflon-coated catheters have been used as a standard control for antibiotic-coated catheters such as silver-coated and nitrofurazone-coated [37,38].

\subsection{Polyzwitterions Coatings}

Polyzwitterions are a good example of a modification that results in repulsion of microbes using low surface energies. These polymers have equal positive and negative charges, resulting in a neutrally charged molecule, which affects the Gibbs free energy resulting in a hydrophilic layer that repels bacteria binding [45]. A study, using an in vitro bladder model, evaluated the ability of the zwitterionic polymer (2-methacryloloxyethylphosphorylcholine co-polymerized with long-chain alkyl methacrylates)-coated catheters to repel P. mirabilis colonization. The results showed that this modification could neither repel nor prevent $P$. mirabilis attachment or biofilm formation nor encrustation of the catheter by calcium and magnesium deposits on either silicone or latex based modified catheters [40].

Poly(sulfobetaine methacrylate) (PSBMA) polymers have been used to modify silicone (PDMS) catheters. A study tested PSBMA ability to reduce biofilm formation in an in vitro bladder-catheterization model. In this study, a silicone catheter was modified in sections some containing PSBMA and others not. The result showed that the reduction of Pseudomonas aeruginosa and Staphylococcus aureus biofilm was dependent on the PSBMA-modified section [41].

Currently, polyzwitterions coatings require additional research to characterize their antifouling activity and effectivity in reducing microbial colonization.

\subsection{Poly(Ethylene Glycol) (PEG)-Coatings}

PEG-coatings are attractive because of their nonimmunogenic, nonantigenicity, and protein repellent properties [42]. It has been demonstrated that PEG's polymeric brush layers are able to block the long-range attractive forces of interaction between bacteria and substrates as well as introduce repulsive steric effects [62]. An in vitro study looked at PEG as an antifoulant in combination with a polycarbonate brush containing dopamine (to act as an anchor) and antibacterial cations coated onto silicone. The results showed that PEG-antimicrobial-coating had both antifouling and antimicrobial properties against $S$. aureus and Escherichia coli [46]. Another in vitro study investigated the ability of PEG to block bacterial adhesion, finding that PEG inhibited E. coli bacterial adhesion on polyurethane surfaces but was unsuccessful against Staphylococcus epidermidis attachment. However, S. epidermidis 
showed inconsistent binding to the surface, this variability was attributable to the culture media used. Despite the fact that urine would be the most accurate medium to test, this study only used laboratory defined-media [44]. In addition to PEG antifouling properties, PEG has been used as a mechanism of impregnating catheters with chlorhexidine, a known disinfectant and antiseptic [63]. Based on these studies, PEG seems to be a good antifouling candidate to test in vivo.

\subsection{Surface Topography Modifications}

Modifications to the topography of surfaces have been applied with the goal to decrease bacterial adhesion [48]. Many of these modifications have been inspired by nature; for example, mimicking surfaces such as sharkskin, gecko feet, and flower peddles, which naturally discourage biofilm formation [47]. One in vitro study explored the effects of micro- and nanoscale topography on bacterial attachment. Here, the authors tested four distinct topographies against attachment of E. coli, Listeria innocua, and Pseudomonas fluorescens grown in Tryptic Soy Broth (TSB) media under static conditions. They found that micro- and nanoscale patterning decrease biofilm formation in all bacterial strains. However, there was no universal relationship between the surface topography and biofilm inhibition. Additionally, the attachment to the different surfaces varied with each strain. Although not directly tested in the context of urinary catheter, these surface modifications show potential for such an application $[47,49]$.

Another in vitro study investigated the impact of sharklet micropatterned surfaces with the goal to create a material that will reduce the risk of CAUTI. In this study, the authors tested three sharklet micropatterned silicone pieces against uropathogenic E. coli colonization and migration. For assessing bacterial colonization, E. coli was grown to log phase in either TSB media or artificial urine, then modified silicones were immerged in the bacterial solution and incubated for different time points. All three modifications reduced bacterial binding up to $47 \%$. In addition, these modifications reduced E. coli movement in an agar migration assay by more than $80 \%$. From these results, the authors concluded that the sharklet micropatterns are an option for preventing CAUTI [50].

Although surface topography modifications show efficiency in vitro, it is important to test them in vivo since urinary catheterization induces an inflammation response causing urothelial cell exfoliation and releasing serum proteins [64-66], which may cover these modifications affecting their function.

\subsection{Enzymes}

A variety of host enzymes have been tested for antibiotic activity through diverse mechanisms, including quorum quenching, hydrolytic bonds, and reversible bonds. In this section, we will review the role of acylase, cellobiose dehydrogenase, $\alpha$-chymotrypsin, glycoside hydrolases, and their activity against bacterial catheter colonization.

\subsubsection{Acylase}

Quorum quenching activity is not bactericidal but inhibits biofilm formation; thus, the potential for drug resistance development is minimal. Quorum quenching was tested by using a combination of alpha-amylase and acylase [28]. Alpha-amylase interferes with assembly of the extracellular matrix and the acylase interferes with quorum signaling by degrading the small signaling molecules and disrupting the microbes' ability to communicate with its neighbor to form biofilms. When tested in vitro, this coating was able to reduce P. aeruginosa biofilms by over $40 \%$, S. aureus biofilms by over $30 \%$ and co-cultured biofilms by over 50\%, although planktonic growth was not inhibited. In vivo biofilm formation on the catheter's balloon section was decreased by $90 \%$, although this was not seen in the lumen of the catheter. Furthermore, the quorum quenching action of acylase alone on catheter material was confirmed in a later study by the same group [56]. 


\subsubsection{Cellobiose Dehydrogenase (CDH)}

$\mathrm{CDH}$ is an antimicrobial enzyme able to use various oligosaccharides as electron donors to produce hydrogen peroxide, which is a well-known antimicrobial agent. $\mathrm{CDH}$ was immobilized on the surface of silicone, its stability was assessed in urine showing that hydrogen peroxide was released for over 16 days and that inhibit $S$. aureus biofilm formation [58]. Another study attached $\mathrm{CDH}$ nanoparticle layers onto silicone's surface by applying ultrasonic waves. This $\mathrm{CDH}$-coated silicone surfaces were tested against $S$. aureus, finding that the attached $\mathrm{CDH}$ produced $18 \mu \mathrm{M}$ of hydrogen peroxide within $2 \mathrm{~h}$, which was sufficient to significantly reduce the amount of viable $S$. aureus as well as reducing attachment to the surface [43].

\subsection{3. $\alpha$-Chymotrypsin $(\alpha-\mathrm{CT})$}

$\alpha-\mathrm{CT}$ is a serine endopeptidase that cleaves peptide bonds by attacking the unreactive carbonyl group [52]. Based on the properties of $\alpha$-CT, Catto and collaborators assessed whether $\alpha$-CT will disrupt biofilm formation [55] since biofilm matrix consists of proteins, extracellular DNA, and polysaccharides [67]. In this in vitro study, $\alpha$-CT was covalently immobilized on a low-density polyethylene (LDPE) pieces and incubated with LB media containing E. coli MG1655 in a CDC biofilm reactor with continuous stirring. They found that the LDPE- $\alpha$-CT significantly reduced the number of adherent cells, affecting the biofilm thickness, roughness and coverage. Additionally, the bio-volume of the polysaccharide matrix decreased. The authors conclude that the anti-biofilm properties of LDPE- $\alpha$-CT may potentiate the activity of antimicrobials since the majority of the population would be in a planktonic form [55].

\subsubsection{Exopolysaccharide-Specific Glycoside Hydrolase}

Exopolysaccharides are a crucial component of bacterial biofilm development and architecture, providing protection against antibacterial agents and host immune defense [67]. Glycoside hydrolases (Ghs) selectively target and hydrolyze the glycosidic bonds of exopolysaccharide components of the biofilm matrix [54]. Based on its properties, Ghs have been proposed as anti-biofilm agents [54,57]. Baker and collaborators evaluated Ghs potential as treatment against Pseudomonas aeruginosa biofilm formation. Overnight cultures of P. aeruginosa PAO1 and other clinical strains were diluted in Luria-Bertani (LB) media; then the diluted cultures were added to sterile 96 -well polystyrene microtiter plates and incubated for $24 \mathrm{~h}$ under static conditions. Different concentrations of Ghs were added at time 0 or in established biofilms, showing prevention or disruption of biofilm formation, respectively. Furthermore, they found that Ghs potentiate antibiotics and ameliorate human neutrophil killing [54]. Another group used Ghs as a new anti-fouling coating against P. aeruginosa biofilms [53]. They used a specific Ghs that targets Psl, a neutral exopolysaccharide, and covalently immobilized it to silica glass, PDMS, and polystyrene (PS) surfaces. To assess biofilm formation P. aeruginosa PAO1 were grown statically on the PslGh-immobilized surfaces and non-treated surfaces at different time points up to 8 days. They found that PslGhs was able to reduce 3-logs in the surface associated bacteria. The authors concluded that these results have significant implications for surface design of medical devices since it keeps bacteria in a planktonic state, where they are susceptible to antimicrobials [53].

In conclusion, from all these antifouling surfaces, only hydrogel- and PTFE-coated catheters have been tested in clinical trials, yielding contradictory results. However, despite the hydrogel's contradictory results, their commercial availability has made them popular as a base for antimicrobial impregnation $[27,28]$. In many clinical trials, hydrogel catheters are used as the control or the standard of care catheter presumably because that was the type of catheter the hospital was using at that time $[27,28]$. Hydrogel catheters have being impregnated with silver molecules, bacteriophages, liposomes containing antibiotics, among others [27,60,61,68-71]. Furthermore, hydrogel silver-coated catheters have been commonly used in hospital settings [28] but like many of the coatings discussed in this review, evidence for their efficacy is uncertain. 
Overall, despite the promising in vitro results from polyzwitterion and PEG polymers, surface topography modification and enzymes-coated surface, the modification need to be tested in an animal model of CAUTI to validate their efficacy.

\section{Approaches to Restriction of CAUTI by Antimicrobial Coatings}

Antimicrobials have been the most popular coating and make up the majority of recent research due to their ability to target microbes in a variety of ways, which can be summarized into five broad functions: (1) inhibition of cell wall synthesis; (2) inhibition of protein synthesis; (3) inhibition of nucleic acid synthesis; (4) targeting cell membrane sterols; and (5) inhibition of unique metabolic steps $[15,28]$. Within each of these groups are unique antimicrobials that target conserved factors among all bacterial species or target factors for specific bacterial strains. Ideally, the perfect catheter material would contain an antimicrobial that targets the majority of the pathogens but this comes with challenges as conserved targets between bacterial species are often found in mammalian cells as well, having the risk to cause side effects in the patient.

The most popular antimicrobials include metal ions, antibiotics, and nitric oxide; however, new groups of catheter coatings are becoming relevant including antimicrobial peptides, bacteriophages, natural bioactive molecules, and microbe responsive coatings. Even though there is an extensive list of potential coatings/modifications for urinary catheters, this section will focus on modifications that have already been tested specifically for use in urinary catheters in vitro and/or in vivo.

\subsection{Metal-Based Approaches}

\subsubsection{Silver Ions}

Silver ions are the most popular clinically tested and available coating for urinary catheters yet the effectiveness of them is still debatable due to vast differences in outcomes in vitro, in animal models and in clinical trials studies [34,51,72-86]. The mechanisms by which silver is toxic to bacteria include disruption of the membrane, proteins, and by inducing oxidative stress through the release of silver ions into the bladder [15].

In Vitro Studies:

Silver-coated catheters have been studied in vitro using a variety of assays, including zone of inhibition, broth diffusion (put the catheter in inoculated broth and determined how long it visibly inhibited growth), and biofilm formation. Here are some examples of in vitro assessments of silver-coated catheter effectiveness. A study compared E. coli and E. faecalis binding to commercially available silver-silicone-hydrogel, nitrofurazone-silicone, silicone-hydrogel, pure silicone, silver-latex-hydrogel, and latex-hydrogel catheters. Catheter pieces $(6.5 \mathrm{~cm})$ were incubated in sterile laboratory media for $0,3,5,7$, or 10 days, then the integrity of the coatings was tested by incubating with E. coli or E. faecalis in broth for $18 \mathrm{~h}$. They found that silver-coated catheters had no significant effect on bacterial adherence in this model while nitrofurazone-coated pieces significantly decreased bacterial binding. These results do not support a role for silver urinary catheters to prevent CAUTI by decreasing bacterial adherence [74].

Another study compared silver-coated catheters to sparfloxacin-coated and uncoated siliconized latex catheters for their efficacy in growth inhibition and biofilm formation of E. coli, S. aureus, and S. epidermidis for $72 \mathrm{~h}$. Results showed that sparfloxacin-coated catheters were less colonized by the pathogens when compared with silver-coated catheters and uncoated catheters [79].

In Vivo Studies:

Silver-coated catheters have been tested in vivo using different animal models, showing diverse effectiveness. Madnakhalikar and collaborators used a mouse model to evaluate the ability of silver-embedded polymers to decrease infection by E. coli. In the mouse model, catheters made 
of silicone tubing (control) or silicone tubing with silver embedded were inserted into the bladder, followed by $50 \mu \mathrm{L}$ of $E$. coli, then after $30 \mathrm{~min}$ of the inoculation, the bacteria was removed. After 14 days post infection, the silver-coated catheter showed reduced overall colonization and dissemination of E. coli when compared with the uncoated silicone [83]. Another randomized study of 36 dogs was conducted where half were given a silver-coated catheter and the other half given an uncoated catheter. No statistical difference in the incidence of CAUTI was found, but the mean time to bacteriuria was shorter for the silver-coated group [84].

\section{Clinical Studies:}

In clinical trials, the silver-coated catheters have shown inconsistent results. There are several studies showing that silver coatings are superior in reducing CAUTI than standard urinary catheters. For example, a clinical trial of over 27,000 patients comparing silver-alloy hydrogel-coated catheters vs. siliconized latex catheters, found that the silver-alloy hydrogel-coated catheters decreased the risk of infection by $32 \%$ and was estimated to save the hospital between $\$ 14,000$ and $\$ 500,000$ [78]. Another clinical trial showed that silver alloy hydrogel reduced 31\% the incidence of CAUTIs when compared with uncoated latex catheter [73]. Lastly, Lederer and collaborators compared silver-alloy hydrogel catheters with the hospitals' standard catheter, finding that silver-alloy hydrogel catheters reduced the incidence of CAUTI to $58 \%$ or $47 \%$, depending on the CAUTI definition given by the National Healthcare Safety Network (NHSN) or specified clinical criteria, respectively [80].

On the contrary, other studies have shown no advantage of using a silver-coated catheter. For example, Bologna and collaborators did not find a statistical difference when comparing silver-alloy hydrogel catheters with latex catheters; however, they did observe a trend supporting silver-alloy-coated catheters [72]. Thibon and collaborators also showed no significant difference in the CAUTI incidences between silver-hydrogel-coated catheters and standard catheters when CAUTI was defined as $>10^{5}$ colony forming units (CFU) of bacteria and $>10$ leukocytes per $\mathrm{mm}^{3}$ [86]. Similarly, Lam and collaborators showed through an extensive literature review that silver-alloy-coated catheters did not show a reduction of CAUTI, but did show a higher level of comfort for patients in comparison to nitrofurazone catheters [27]. Lai and collaborators found no significant reduction in a clinical trial comparing CAUTI rates and the expense of silver-alloy hydrogel-coated catheters with a baseline CAUTI rate and cost of standard non-coated catheters. Although, they suggested that the silver catheter created mild savings for the hospital [87].

Additionally, several silver-coated catheters have been compared showing different efficacies depending on the silver-coated method used. For example, a small clinical trial of 63 subjects catheterized for more than $24 \mathrm{~h}$ after surgery compared silver-alloy-coated hydrogel catheters (control) with a novel (proprietary) silver-impregnated catheter (test). This study showed a trend to lower rates of asymptomatic bacteriuria within the test group, but it was concluded that further testing is needed due to the small size. [81].

Furthermore, several review articles have done a cost analysis for different modified catheters vs. standard silicone catheters and concluded that silver-coated catheters were 'very unlikely' to be cost-effective when compared to nitrofurazone-coated catheters and other standard catheters. This conclusion was drawn from the higher cost of silver-coated catheters in relation to the reduction in health care costs due to the instances of CAUTI [27,37].

Overall, silver-coated catheters show a diverse array of results and are not cost effective relative to other options, making it difficult to justify their use. This may be due in part to the variety of adhesion methods and forms of silver used in the different studies. Further analyses are needed to evaluate the effectiveness of different coating methods.

\subsubsection{Nanoparticles}

Nanoparticles have become popular as a drug delivery system since they improve bioavailability by enhancing solubility, stability, and biodistribution [88]. Nanoparticles have been used to deliver 
metals including silver [51,85,89-91], gold [92], copper [93-95], and zinc [96]. These metal nanoparticles in the context of urinary catheters will be discussed below.

Silver Nanoparticles:

Silver ions have shown mixed results as described above. Additionally, to their toxicity to the host, silver ions irreversibly bind to proteins or molecules, decreasing their antimicrobial activity [89]. However, despite their shortfalls, silver has been incorporated into nanoparticles to overcome some of the negative effects and shown almost identical mechanisms of action $[89,90]$. Roe and collaborators showed that silver nanoparticles-coated plastic catheters reduce biofilm formation and growth of several pathogens including E. coli, Enterococcus spp. S. aureus; P. aeruginosa; coagulase-negative staphylococci; and Candida albicans, when compared to uncoated catheters. Additionally, they showed that the silver-coated catheter did not induced inflammation or toxicity when implanted in the dorsal thoracic subcutaneous cavities of male mice. They also showed that the silver molecules released by the catheter were mainly excreted in the feces or held at the site of implant in a period of 10 days [85]. However, inflammation and toxicity assessment would be more reliable in an animal model of CAUTI, since the bladder environment is different from a subcutaneous environment. Alshehri and collaborators showed that silver nanoparticles embedded in hydrogel coating were successful in inhibiting growth of E. coli, Klebsiella pneumoniae, P. aeruginosa, Proteus vulgaris, S. aureus, and P. mirabilis [51]. Despite these positive results, their overall antimicrobial efficiency compared to silver ions is still debated [89].

\section{Gold Nanoparticles:}

The antibacterial activity of these particles is attributable to attachment of the nanoparticles to the bacterial membrane followed by disruption of membrane potential and reduction of ATP level as well as inhibition of transfer ribonucleic acid (tRNA) binding to the ribosome [97]. Gold nanoparticles have been tested in vitro against uropathogens including S. aureus, K. pneumonia, P. aeruginosa, and Enterococcus faecalis. This study assessed the efficacy of gold nanoparticles in inhibiting bacterial growth. A bacterial inoculum was spread onto Muller Hinton agar plates with or without the nanoparticles and were incubated for 24 and $48 \mathrm{~h}$ and $96 \%-100 \%$ at $48 \mathrm{~h}$ [92]. However, since longer timepoints were not tested, the fact that the bacterial inhibition was not $100 \%$ at $48 \mathrm{~h}$ brings into question whether gold-resistance is emerging.

\section{Copper Nanoparticles:}

Antimicrobial properties of copper $(\mathrm{Cu})$ affects the bacterial cell by entering and binding to DNA-phosphate site and degrading DNA, inactivating essential bacterial enzymes, and causing membrane and cell wall disruption $[93,94,98,99]$. These interactions lead to cell damage and trigger cell death $[93,94,99]$. An in vitro study done by Rtimi and collaborators tested the antimicrobial activity of $\mathrm{Cu}$ and silver against $E$. coli [100]. The authors incorporated $\mathrm{Cu}$ alone or in combination with silver onto polyurethane catheter surfaces using a new coating technique that involves using low temperatures/high vacuum magnetron sputtering, providing a uniform and high quality $3 \mathrm{D}$ sputtering [100,101]. Then, E. coli K12 (ATCC23716) culture was added on coated and uncoated catheters and samples were taken at different timepoints up to $30 \mathrm{~min}$ and viable bacteria was quantified by CFU counts and by microscopy using live/dead staining. They found that by $2 \mathrm{~min}$ of interaction of the bacteria with the coated surfaced, no viable bacteria was recovered [100].

\section{Zinc-Doped Copper Oxide Nanoparticles:}

Although zinc $(\mathrm{Zn})$ has antimicrobial properties, the exact antimicrobial mechanism is not clear. However, it has been suggested that induced production of hydrogen peroxide is a main factor of antibacterial activity and has been used in combination with copper oxide $(\mathrm{CuO})$ to reduce bacterial colonization [93]. For example, Shalom and collaborators tested $\mathrm{Zn}$-doped copper oxide $(\mathrm{CuO})$ nanoparticle antimicrobial activity both in vitro and in an in vivo rabbit model of CAUTI [96]. 
Commercially available urinary catheters coated with $\mathrm{Zn}$-doped $\mathrm{CuO}$ nanoparticles were found to inhibit over $90 \%$ of biofilm formation by E. coli ATCC 25922, S. aureus ATCC 29213, and P. mirabilis in Muller Hinton broth for $24 \mathrm{~h}$ under flow conditions when compared to the uncoated catheter [96]. Furthermore, rabbits were catheterized with uncoated and coated-catheters and infected for 7 days. They used scanning electron microscopy (SEM) images to show significant reduction in biofilm formation and urine samples obtained throughout catheterization to show lower CFU counts in animals catheterized with the nanoparticle coated catheter [96]. These results were supported by a previous in vitro study done by Agarwala and collaborators. They tested $\mathrm{CuO}$ nanoparticles against S. aureus and E. coli, finding significant antibacterial activity in zone of inhibition tests. This group also tested iron nanoparticles against these pathogens and found it was not as effective as the $\mathrm{CuO}$ nanoparticles [95].

In conclusion, from all the metal-based coatings, silver ions and silver nanoparticles have been extensively tested; however, mixed results have been obtained in clinical studies. It will be of importance to understand the host factors that may play a role in their efficacy. Additionally, we have shown that $\mathrm{Cu}$ nanoparticles in combination with $\mathrm{Zn}$ and silver nanoparticles showed great antimicrobial activity; however, we need to understand their toxicity levels to the host before bringing these modifications into practice.

\subsection{Antibiotics}

Antibiotics have been used to fight bacterial infections and are the recommended treatment against CAUTI. Over the past few decades, researchers have designed and obtained approval for antibiotic-coated urinary catheters for use in clinical settings. However, due to the higher cost and contradictory results from in vitro studies and in clinical trials, their efficacy is brought into question $[4,25,63,74,77,79,91,102-113]$. The most common antibiotics used include nitrofurazone, gentamicin, fluoroquinolones (norfloxacin, ciprofloxacin, sparfloxacin), triclosan, and chlorhexidine.

\subsubsection{Nitrofurazone}

Nitrofurazone-impregnated catheters are an example of an antimicrobial catheter available in clinics $[37,102]$. Nitrofurazone inhibits DNA replication thus inhibiting growth and biofilm formation [28]. Nitrofurazone-impregnated catheters have been tested against E. coli, K. pneumoniae, Citrobacter freundii, S. aureus, coagulase-negative staphylococci, and Enterococcus faecium, finding that the catheter was able to inhibit growth of all multidrug resistant and susceptible strains with the exception of vancomycin resistant $E$. faecium [77].

Although the above in vitro study shows promise for success in vivo, unfortunately, nitrofurazone catheters have yielded mixed results in clinical settings. A randomized clinical trial comparing nitrofurazone-impregnated silicone catheters and non-coated silicone catheter found no reduction on the incidence of CAUTI or bacteriuria [102]. On the contrary, a review of clinical trials showed a reduction of symptomatic CAUTI when nitrofurazone catheters were used in place of teflon-coated latex catheters with a boarder-line significant drop in CAUTI frequency. Another clinical trial comparing nitrofurazone-impregnated catheters with uncoated catheters in patients that were catheterized for less than 1 week showed a lower rate of bacteriuria in the nitrofurazone group $[27,91]$.

Patient comfort is also an important factor to account for when testing new material coatings. Unfortunately, nitrofurazone catheters have been reported to be uncomfortable for patients $[15,27,28]$. Importantly, in May 2002, the U.S. Food and Drug Administration (FDA) discontinued approval of nitrofurazone as a topical antiseptic for food-animals and human treatment as it has been shown to be carcinogenic [FDA]. This ban applies to over the counter use of topical nitrofurazone thus, catheters are not included in this reform. Therefore, they are still available for clinic use but interest has slowed and research has turned away from nitrofurazone [28]. 


\subsubsection{Gentamicin}

Gentamicin is a bactericidal broad spectrum aminoglycoside antibiotic (except against streptococci and anaerobic bacteria). It acts by inhibiting protein synthesis by binding the bacterial $30 \mathrm{~S}$ ribosomal subunit [114-116]. Gentamicin-coated catheters have been tested in a rabbit model of CAUTI, showing that it successfully reduced the incidence and severity of infection in short-term catheterization. This in vivo experiment was done following promising in vitro tests showing antimicrobial activity and sustained release of the antibiotic over 8 days by embedding the gentamicin in polyethylene-covinyl acetate (EVA) [103]. Additionally, evaluation of the release of gentamicin when embedded in EVA/poly(ethylene oxide) (PEO) was assessed, showing that the gentamicin release was significantly dependent on the coating layer [104]. Moreover, another research group showed that addition of PEG to gentamicin was superior in controlling the release of gentamicin for up to 12 days, extending the previous 8 day release [117]. This group emphasized the release of gentamicin could be manipulated by changing the amount of PEG and initial gentamicin concentration. Despite all the in vitro and in vivo data, further development of gentamicin-coated catheters for use in clinical trials has not yet been described.

\subsubsection{Fluoroquinolones}

Fluoroquinolones are broad spectrum antibiotics that act by binding to bacterial DNA gyrase and blocking bacterial DNA replication [118]. DNA gyrase is an important bacterial enzyme that introduces ATP-dependent negative supercoiling of double-stranded DNA [118,119]. Here we will review three fluoroquinolones (norfloxacin, ciprofloxacin, and sparfloxacin), which have been used to impregnate urinary catheters.

Norfloxacin:

Norfloxacin has been used to coat catheter materials and has shown a reduction of bacterial growth in vitro using inhibition zone tests against E. coli, K. pneumoniae, P. vulgaris, and P. aeruginosa [105,106]. Additionally, Norfloxacin has shown efficacy when combined with other antibiotics against biofilm formation in vitro. For example, in combination with 3\% ciprofloxacin and $6 \%$ azithromycin showed a sustained release over a period of 4 weeks and a shelf life of 1 year including significant inhibition of microbial growth. This study also concluded that at this concentration, bactericidal activity was effective as early as $24 \mathrm{~h}$ [120]. However, norfloxacin-coated catheters efficiency in vivo and in clinical trials has not been evaluated.

\section{Ciprofloxacin:}

In an in vivo rabbit model, ciprofloxacin liposomes-impregnated hydrogel Foley catheters were compared to an uncoated hydrogel catheter and then tested against $E$. coli CAUTI. By culturing urine, it was found that development of CAUTI was delayed from 3.5 days in uncoated catheters to 5.3 days in the modified catheter with ciprofloxacin [70].

\section{Sparfloxacin:}

An in vitro experiment testing sparfloxacin-coated latex catheters ability to prevent $E$. coli and $S$. aureus binding using both agar and broth diffusion assays showed significant inhibition of bacterial binding when compared to silver-coated and uncoated catheters [79]. Besides this study, not other in vitro and in vivo studies have been done using sparfloxacin-coated catheter.

\subsubsection{Triclosan}

Triclosan is a molecule that inhibits the enzymatic activity responsible for fatty acid synthesis [112]. At low levels, it is considered bacteriostatic while at higher levels it is bactericidal [121]. Fatty acid synthesis is necessary for cellular function and growth as it is responsible for phospholipid formation 
and thus membrane formation. Triclosan has been used as an antiseptic for decades and it is commonly found in household products such as toothpaste and soaps [122]. Recently, triclosan has been proposed as a candidate for coating medical devices, since it chemical properties make it easy to coat the catheter material [113]. Although much research has shown the antimicrobial activity in vitro, its effects on the human body have not been fully studied. This is particularly concerning as triclosan has been removed from use by health care professionals in hospitals and other health care settings [123]. Nevertheless, since there has been no data in humans that shows triclosan leading to antimicrobial resistance, the benefits have compensated for the cost [113]. However, recently researchers have reported triclosan promotes antibiotic tolerance in bacteria both in vitro and in vivo [109,122,123], which fuels the controversy over the efficacy and use of triclosan.

\subsubsection{Chlorhexidine}

Chlorhexidine is a bacteriostatic molecule at low levels, but at high levels, it is considered bactericidal [124]. Chlorhexidine has a variety of effects on both bacteria and fungi but has a relatively low toxicity in mammals and is commonly used to wash materials and maintain aseptic conditions when placing a urinary catheter $[63,109]$. Studies have tested the effectiveness of chlorhexidine when used to rinse out the bladder during catheterization to prevent microbial colonization and found it to be very effective when compared to saline washes [110]. Chlorhexidine has been added to catheters using a variety of techniques, from being impregnated into catheters to directly attach to its surface [108]. For example, in an in vitro experiment, chlorhexidine-filled nanoparticles were successfully spray-adhered, showing sustained released and efficiency to decrease uropathogen adhesion for up to 14 days [111]. Another form of chlorhexidine release has been explored employing a polymer matrix (varnish) with the molecule embedded. The varnish showed a peak in release in the first few hours, then a slow release for the $24 \mathrm{~h}$ tested. More importantly, when the chlorhexidine imbedded matrix was submerged in fresh P. aeruginosa inoculum every $24 \mathrm{~h}$ for 3 days, the first 2 days showed a significant decrease in bacterial adhesion to the catheter compared to an un-embedded matrix [109]. This study was performed following promising results in vivo to characterize the release of chlorhexidine. The in vivo study was conducted on dogs where catheters in place for greater than $24 \mathrm{~h}$ and up to 6 days, showed a reduction in biofilm formation as well as overall bacterial colonization in chlorhexidine varnish catheters compared to unmodified catheters [63].

In conclusion, antibiotic-coated catheters are promising; however, many pathogens that cause CAUTIs are becoming resistant to even the last line of defense antibiotics such as vancomycin [125]. The use of antibiotics is deterred by the bacteria's ability to become resistant to antibiotics and to form biofilms on the catheter, generating further antibiotic tolerance [126,127]. Given that antibiotics have different minimal inhibitory concentrations depending on the bacterial group, and that the microbial species diversity that causes CAUTIs is extensive, multiple antibiotics should be used for coating urinary catheters to increase its effectiveness and decrease the potential development of antibiotic resistance.

\subsection{Nitric Oxide}

Nitric oxide (NO) has been used as an antimicrobial for the past five decades and has repeatedly demonstrated its potential for biomedical application [128,129]. NO covalently binds DNA, proteins and lipids, thereby inhibiting or killing the pathogens [130]. Traditionally NO-donors have been added to the surface of polymers to curb bacterial attachment, but few studies have addressed its efficacy when coating urinary catheters $[28,129]$. One such study showed in vitro that gaseous NO-impregnated catheters have a sustained NO release over 14 days with stable storage. Additionally, NO prevented biofilm formation and planktonic growth [129]. Furthermore, another in vitro study showed that $\mathrm{NO}$ release rate was faster in the first $24 \mathrm{~h}$ when placed in urine instead of water. This faster release was attributed to the $\mathrm{pH}$ difference [128]. If acid environment contributes to NO release, a study evaluating the $\mathrm{NO}$ release in different urine $\mathrm{pH}$ environments is necessary since the $\mathrm{pH}$ of the urine 
in patients is variable, which could affect its efficacy. Furthermore, NO has been shown to play an important role in vasodilatation, neurotransmission, angiogenesis, modulation of wound healing, and nonspecific responses to infection [129]. Thus, further studies are needed to understand the NO effects in the bladder.

\subsection{Antimicrobial Peptides}

Antimicrobial peptides (AMPs) are host defense peptides with robust antimicrobial activity against a variety of pathogens [87]. AMPs possess a net positive charge that interacts with negatively charged bacterial membranes and other cell components such as lipopolysaccharides, leading to destabilization and permeabilization $[28,131]$. AMPs can be purified from humans, animals, plants, and bacteria as well as synthesized in a lab and come in a very wide variety of structures [132]. Recently they have become popular as a candidate for catheter modifications; however, the antimicrobial properties vary from peptide to peptide [87]. Here we are reviewing in vitro assessment of several AMP candidates' antimicrobial activity.

An in vitro study showed that attachment of two short arginine (R), lysine (K), and tryptophan (W) rich AMPs, i.e., RWKRWWRRKK (RK1) and RKKRWWRRKK (RK2) to an allyl glycidyl ether (AGE) polymer brush on a silicone surface, killed over $80 \%$ of E. coli, S. aureus, and C. albicans in a variety of culture media and reduced their ability to form biofilms on the surface up to 3 days [87]. Monteiro and collaborators isolated the AMP Chain201D (KWIVWRWRFKR) from crowberries, and demonstrated that this AMP has antimicrobial activity against relevant ATCC and clinical strains. This peptide also showed antimicrobial activity against E. coli and S. aureus when immobilized on a silicone based surface. These data further strengthen its candidacy for use on urinary catheters [133]. Another AMP candidate, CWR11 (CWFWKWWRRRRR-NH2), was tethered to a polydopamine polymer on a silicone surface as well as commercially available Foley catheters. CWR11-coated catheter was tested against E. coli, S. aureus, and P. aeruginosa, showing both antimicrobial activity and lowered bacterial attachment. Additionally, CWR11 did not show cytotoxicity to both urothelial and blood cells in vitro [33]. Furthermore, the synthesized cysteine labeled peptide E6 (RRWRIVVIRVRRC) was immobilized on polyurethane tubing via a polymer brush coating, which allowed for testing both in vitro and in a mouse model of CAUTI. In vitro testing showed a reduction in P. aeruginosa and $S$. aureus ability to bind to the catheter while in vivo showed reduction of $P$. aeruginosa adhesion to the catheter and bacterial titers in the bladder. Additionally, AMP E6 showed biocompatibility when tested against bladder epithelial and fibroblast cells in cell culture [134].

In summary, although AMPs research is still in early research stages as they were only discovered in the 1990s [59], many of these peptides show great catheter coating potential but need to be further tested in vivo and in clinical studies. In vivo studies will provide a better idea of the effects of the bladder environment on the peptides, which are susceptible to enzymatic degradation.

\subsection{Bacteriophages}

Bacteriophages are viruses specific to the bacteria [68]. It is estimated that phage predation reduces the global bacterial population by half every $48 \mathrm{~h}$ [135]. Bacteriophages are argued to be a good option for catheter coatings as: 1) they have potential as biofilm control agents because their specificities can be tailored to target certain pathogens; 2 ) they are self-replicating in the presence of their host cells and are eliminated by the body in the absence of host cells; 3 ) they can be used effectively against multidrug-resistant bacteria; and 4) multiple phages can be combined to broaden the effective range of the treatment $[68,69,135]$. Although, the full timeline of phage activity is still unknown, there is evidence that bacteriophages only delay bacterial biofilm formation [68]. Based on this and results of bacteriophage activity on biofilms have showed potential for bacteriophages to be efficient for short term catheterization [68]. Several bacteriophages have been tested in the context of urinary catheters; here we are discussing the effectiveness of bacteriophages-impregnated catheters against $S$. epidermidis, E. coli, P. mirabilis, and P. aeruginosa catheter colonization. 
In an in vitro study, Phage 456 was impregnated onto a hydrogel Foley catheter and tested against coagulase-negative S. epidermidis biofilm formation, finding that the bacteriophage significantly reduced viable biofilm formation over a 24-h exposure period. Furthermore, supplementation with cations doubled the decrease of CFU counts on the catheter [136]. Another study used T4 or E. coli-P. mirabilis' bacteriophages-impregnated onto hydrogel-coated Foley catheters to test their ability to reduce biofilm formation in vitro. Foley catheters were incubated in a phage-containing solution for $1 \mathrm{~h}$, and then exposed to P. mirabilis or E. coli for $24 \mathrm{~h}$. This study showed that these bacteriophages were able to reduce biofilm formation by over $90 \%$. [135].

Furthermore, another study impregnated hydrogel catheters with a mixture of bacteriophages isolated from wastewater specific to P. aeruginosa (six specific phages) and P. mirabilis (four specific phages) by incubating the catheters with the phages for $1 \mathrm{~h}$. The bacteriophage-impregnated catheters were tested in vitro against $P$. aeruginosa and $P$. mirabilis biofilm formation in artificial urine medium. The biofilm formation was monitored for over 72 and $96 \mathrm{~h}$, finding that biofilm formation was reduced 4 logs in P. aeruginosa and $2 \log$ in P. mirabilis [68]. Additionally, this same group previously tested S. epidermidis and P. aeruginosa with bacteriophages on catheter material and found coatings with multiple phages are more effective than coatings with single phages [137].

Another study raised concerns surrounding a successful trigger for the release of bacteriophages from the surface of the catheter in response to infection. This study used a $\mathrm{pH}$ sensitive polymer layer (EUDRAGIT S 100) by adding it after phage attachment within a hydrogel coating. The goal of this $\mathrm{pH}$-mediated release was not to prevent biofilm attachment but to prevent incrustation of the catheter lumen. The catheters were analyzed by scanning electron microscopy showing a reduction of encrustation [69].

In summary, phage-impregnated catheters hold enormous potential since they do not promote antimicrobial resistance and it is species-specific, preserving the normal microflora. A shortfall of this approach is that a variety of pathogens can cause CAUTI and most of the time there are polymicrobial infections; thus, it is crucial to identify the pathogen in order to target it.

\subsection{Natural Bioactive Molecules}

A variety of bioactive molecules that are natural in origin have been tested for antimicrobial properties, a revolution brought about by the push for more eco-sustainable anti-biofilm molecules [47,138]. Examples of these include natural oils such as eucalyptus and tea tree oils [139-141]. Martur and collaborators tested in vitro the efficacy of eucalyptus essential oil on catheters against P. mirabilis biofilm formation. SEM analysis showed that eucalyptus oil had a strong biofilm inhibitory effect. Another in vitro study assessed the antimicrobial activity of essential oils such as tea tree oil, terpinen, cineole, and eugenol against $P$. mirabilis planktonic and biofilm states in urine. They found that all four oils have antimicrobial effect against both planktonic cells and biofilms. However, eugenol exhibited a greater antimicrobial effect [142].

Salicylic acid is a naturally occurring bioactive molecule with antimicrobial activity [143]. It has been shown that in S. epidermidis, salicylic acid inhibits several bacterial factors such as teichoic acid production, type1 antigen, polysaccharides, and adhesins [144]. Nowatzki and collaborators evaluated E. coli and P. aeruginosa biofilm formation on salicylic acid-coated catheters, finding significant reduction in biofilm formation. Furthermore, they assessed E. coli biofilm formation on the coated catheters in an in vitro urine flow model, showing a reduction on E. coli biofilm formation up to 5 days [143].

In summary, natural biomolecules have shown antimicrobial activity in vitro; however, these biomolecules should be tested in an animal model of CAUTI to further validate their effectiveness prior to clinical testing.

\subsection{Microbe Responsive Coatings}

Microbe responsive coatings are made to respond to the environment that microbes create during infection [145]. These coatings are paired with an antimicrobial, which is released or exposed on 
queue of an environmental factor. An example of these is lipase sensitive linker attaching antibiotics and molecules that have been shown to disrupt quorum sensing of bacteria [145]. In the presence of bacteria which release lipase, the link between the molecule and the catheter surface is broken and the molecule released [146].

\section{Miscellaneous Coatings}

\subsection{Bacterial Interference}

The driving idea behind bacterial interference is to use the native flora (passive interface) or bacteria of low virulence (active interference) to compete against the pathogen by creating colonization resistance [147]. In instances where natural bacterial flora may not provide adequate resistance to colonization and/or infection, active bacterial interference can be useful by intentionally administering into the human body bacteria of low virulence that could replace the pathogens [147].

In a clinical trial, the benefits of bacterial interference were assessed using a benign E. coli strain in male patients with spinal cord injury that practice intermittent catheterization and have experienced at least one UTI episode within a year. Lubricious coated latex catheters (Bardex) were pre-inoculated with E. coli 83972 for $48 \mathrm{~h}$. Then, thirteen patients were catheterized with the pre-inoculated catheters for 3 days. After 43 days after catheter removal, eight out of thirteen patients were still colonized $\left(>10^{2} \mathrm{CFU} / \mathrm{mL}\right)$. Interestingly, the eight colonized subjects had lower rate of UTI of ( 0.77 per patient-year) when compared with their UTI rate prior the enrollment (2.27 UTI per patient-year). The authors concluded that E. coli 83972-coated urinary catheters are a viable means to achieve bladder colonization with this potentially protective strain in persons practicing intermittent catheterization [148].

Another clinical study from the same group assessed whether bacterial interference would prevent CAUTI in patients with long-term indwelling catheters [149]. This study selected ten adult patients requiring a urinary catheter, had at least one prior symptomatic UTI and pre-existing bladder colonization. Prior to the bacteria-coated catheter placement, patients received antibiotics followed by a washout period. During the patient preparation time, Foley catheter (Bardex; Lubricath) were pre-incubated with probiotic E. coli HU2117 strain for $48 \mathrm{~h}$ followed by placement of the pre-coated catheter. The authors followed cultivable microorganisms in the bladder and sampled urine for microbial community profiling using 16S rRNA gene [149]. They found that eight of the ten patients were colonized with E. coli HU2117 for 57.7 days. However, despite the probiotic colonization, the rates of UTI did not change before, during, and after bladder colonization in all ten subjects and the bacterial diversity was not significantly affected by E. coli HU2117. The authors conclude that bacterial interference was not an effective means for preventing bladder colonization by pathogenic bacteria or for preventing CAUTI. The authors agree with the fact that it was a small clinical trial without a control group, making it difficult to draw conclusions. Importantly, two cases of bacteremia were definitively caused by E. coli HU2117, the probiotic strain [149].

In conclusion, there are not enough clinical studies to validate the beneficial use of bacterial interference. Importantly, urinary catheterization changes the bladder environment creating ideal conditions for colonization by even non-pathogenic strains [150]. Therefore, active bacterial interference may become a major problem if the probiotic is able to take advantage of the bladder changes induced by the catheter, causing CAUTI and bacteremia as shown above.

\subsection{Combination Therapies}

Combinatorial therapies have shown positive results in vitro, examples of these combinations are: (1) silver with several antimicrobial or antifouling compounds such as norfloxacin [151], amikacin [82], nitrofurantoin [82], chlorhexidine [152]; phosphorylcholines [75]; hydroxyapatite [76]; or even plasma [153]; (2) polyzwitterions with cellobiose dehydrogenase [45]; (3) antimicrobial peptide temporin 1Tb with EDTA [154]; (4) chlorhexidine with gentian violet against Candida spp. [107], and (5) bacteriophage with a pre-established biofilm of non-pathogenic E. coli HU2117 on catheter against 
P. aeruginosa [155]. In summary, combinatorial therapies have been used to prevent development of drug resistance and also to fight multidrug resistant pathogen.

\section{Perspectives}

\subsection{Inconsistencies in Testing New Coatings}

There is no doubt that many efforts have been made to create new urinary coatings that will prevent and eradicate microbial colonization. However, the fact that there are inconsistencies in the testing strategies both in vitro and in vivo makes it difficult to do a comprehensive evaluation of the different coatings. For example, the majority of the in vitro studies instead of using urine use laboratory rich or defined culture media when testing biofilm formation or survival. Several reports have shown that laboratory culture media do not recapitulate the catheterized bladder environment experienced by pathogens $[64,156,157]$. Additionally, bacterial persistence and survival may be different between laboratory media and urine, since urine culture conditions have been shown to activate different bacterial transcriptional profiles than when grown in defined media $[64,156,158,159]$. Another variability factor is the oxygen concentration during the in vitro assays; many of these tests have been done under shaking conditions, where oxygen is incorporated into the system, accelerating bacterial growth. The amount of oxygen added is based on a variety of factors including culture volume, shaking speed, and culture duration. Maier and collaborators determined a linear relationship for the rate of oxygen transfer $(\mathrm{mmol} / \mathrm{L} / \mathrm{h})$ in $250 \mathrm{~mL}$ flasks with $26 \mathrm{~mL}$ of culture at varying rates of agitation. At 150 rotations per minute $(\mathrm{rpm})$ the oxygen transfer rate was $11 \mathrm{mmol} / \mathrm{L} / \mathrm{h}$ and at $300 \mathrm{rpm}$ the rate was approximately $20 \mathrm{mmol} / \mathrm{L} / \mathrm{h}$. This is important to note because accelerated growth due to oxygenation alters the transcriptional profile of microbes [160]. It has also been shown that biofilm formation induced an oxygen gradient, which led to spatially distinct expression programs by the UTI pathogens tested [161]. Importantly, oxygen concentration in urine from patients has been shown to be relatively low, ranging from $4.2 \mathrm{mg} / \mathrm{L}$ in healthy individuals to $2.8 \mathrm{mg} / \mathrm{L}$ in patients with urinary tract infections $[103,162]$. Together this suggests the amount of oxygen incorporated during shaking is substantially greater than that found in the in vivo bladder environment and the use of shaking for in vitro experiments does not successfully mimic the in vivo environment.

Another issue arises from the media itself, it was discovered that in mice and humans, urinary catheterization causes physical trauma to the lining of the bladder, inducing an inflammatory response and consequently, changing the bladder environment $[66,125,163-166]$. As part of the inflammatory response, serum proteins are released and accumulated into the bladder and deposited onto the urinary catheter $[64-66,150,167]$. Therefore, urinary catheterization creates a new niche that is often not efficiently mimicked in in vitro studies [157], leading to frustration when promising coating modifications fall short in clinical trials.

In addition to culture conditions, there are several inconsistencies on the methods of examination, such as: (1) experiment duration; (2) inhibitory concentration (zone of inhibition plate assay vs. an actual minimal inhibitory concentration assay); or even (3) the type of assay (survival or binding assays or both); of course the selection will be different if testing antifouling vs. antimicrobial coatings. Due to heterogeneity among studies, it is difficult to reliably comment on the clinical potential and efficacy of different coating materials.

\subsection{Challenges in Fighting CAUTIs}

Furthermore, one of the major challenges is to achieve adequate local delivery of the antimicrobial during infection. Often, controlled drug delivery systems rely on sustained passive delivery, although this often results in exposure of bacterial pathogens to sub-lethal antimicrobial doses. Additionally, the release of antimicrobial compounds may also be hindered by the deposition of host proteins onto the catheter due to inflammatory response caused by the urinary catheterization $[64,65,150,166-168]$. All of these together may explain why promising coating technologies in vitro yield mixed results 
when tested in clinical trials [102]. Importantly, the sub-lethal concentration of antimicrobials may potentially contribute to the continued development of multidrug-resistance among uropathogens [69].

Based on the challenges that we are facing with the development of multidrug resistance, it is necessary to move away from antibiotics and elements that are bactericidal. By understanding the host response to urinary catheterization and infection, more efficient coating and modifications can be developed. Recently, it was found that one of the host proteins released by the inflammatory response, fibrinogen, is essential for biofilm formation in vivo by several prevalent uropathogens such as enterococcal strains, methicillin-resistant S. aureus, Acinetobacter baumannii, and even the fungal pathogen C. albicans $[64,65,150,166-168]$. The fact that different groups of pathogens use host proteins for biofilm formation suggests a common pathway for colonization in the catheterized environment. The field should move towards developing more antifouling coatings that inhibits host-protein deposition and biofilm formation. Targeting a universal host factor that is important for establishing colonization by a variety of microbes will be more effective than targeting a group of pathogens, or a single species, by using other coatings (i.e., antibiotics or bacteriophages), since our current understanding of CAUTI does not allow to predict what type of pathogen will infect a specific patient. Moreover, by preventing biofilm formation without antimicrobial pressure, the contribution to antimicrobial resistance will be null or minimal.

\section{Conclusion}

Despite numerous prevention and treatment strategies [125], CAUTIs are still a major health care burden. Extensive research has been focused in prevention approaches, targeting microbial adhesion, subsequent colonization, and biofilm formation. One of the major areas of research is the development of antifouling and/or antimicrobial catheter coatings, which has generated promising modifications against a variety of microbes. However, the major problem with these coatings is their unsuccessful translation into clinical settings. As discussed in this review, even modifications that have made into medical practice have shown inconsistencies in effectiveness supporting this failed transition. Therefore, the question is: why do such promising coatings that come out of research fall short when translated to the bedside? One explanation is that there are major discrepancies in experimental testing and lack of in vitro recapitulation of the host environment. For this reason, it is essential that potential coatings in an in vitro phase should be tested in conditions that mimic the catheterized bladder environment and needs to be tested in an animal model of CAUTI before reaching clinical trials.

Author Contributions: Conceptualization, A.L.F.-M. and M.J.A.; Resources, A.L.F.-M.; writing-original draft, A.L.F.-M. and M.J.A.; writing-review and editing, A.L.F.-M. and M.J.A.; supervision, A.L.F.-M.; project administration, A.L.F.-M; funding acquisition, A.L.F.-M. All authors have read and agreed to the published version of the manuscript.

Funding: This research received no external funding. This work was supported by institutional funds and the Catalyst Seed Grant from the University of Notre Dame (to A.L.F.-M. and M.J.A.)

Acknowledgments: The authors thank Santiago-Tirado for his suggestions and comments.

Conflicts of Interest: The authors declare no conflict of interest.

\section{References}

1. Davoodian, P.; Nematee, M.; Sheikhvatan, M. Inappropriate use of urinary catheters and its common complications in different hospital wards. Saudi J. Kidney Dis. Transpl. 2012, 23, 63-67. [PubMed]

2. Saint, S.; Wiese, J.; Amory, J.K.; Bernstein, M.L.; Patel, U.D.; Zemencuk, J.K.; Bernstein, S.J.; Lipsky, B.A.; Hofer, T.P. Are physicians aware of which of their patients have indwelling urinary catheters? Am. J. Med. 2000, 109, 476-480. [CrossRef]

3. Trautner, B.W.; Hull, R.A.; Thornby, J.I.; Darouiche, R.O. Coating urinary catheters with an avirulent strain of Escherichia coli as a means to establish asymptomatic colonization. Infect. Control Hosp. Epidemiol. 2007, 28, 92-94. [CrossRef] [PubMed] 
4. Darouiche, R.O.; Mansouri, M.D.; Gawande, P.V.; Madhyastha, S. Efficacy of combination of chlorhexidine and protamine sulphate against device-associated pathogens. J. Antimicrob. Chemother. 2008, 61, 651-657. [CrossRef]

5. Feneley, R.C.; Hopley, I.B.; Wells, P.N. Urinary catheters: History, current status, adverse events and research agenda. J. Med Eng. Technol. 2015, 39, 459-470. [CrossRef]

6. Jarrell, A.S.; Wood, G.C.; Ponnapula, S.; Magnotti, L.J.; Croce, M.A.; Swanson, J.M.; Boucher, B.A.; Fabian, T.C. Short-duration treatment for catheter-associated urinary tract infections in critically ill trauma patients. J. Trauma Acute Care Surg. 2015, 79, 649-653. [CrossRef]

7. Niel-Weise, B.S.; van den Broek, P.J. Urinary catheter policies for long-term bladder drainage. Cochrane Database Syst. Rev. 2012, CD004201. [CrossRef]

8. Bhatia, N.; Daga, M.K.; Garg, S.; Prakash, S.K. Urinary catheterization in medical wards. J. Glob. Infect. Dis. 2010, 2, 83-90.

9. Trautner, B.W.; Darouiche, R.O. Catheter-associated infections: Pathogenesis affects prevention. Arch. Intern. Med. 2004, 164, 842-850. [CrossRef]

10. Weinstein, J.W.; Mazon, D.; Pantelick, E.; Reagan-Cirincione, P.; Dembry, L.M.; Hierholzer, W.J., Jr. A decade of prevalence surveys in a tertiary-care center: Trends in nosocomial infection rates, device utilization, and patient acuity. Infect. Control Hosp. Epidemiol. 1999, 20, 543-548. [CrossRef]

11. Greene, M.T.; Fakih, M.G.; Fowler, K.E.; Meddings, J.; Ratz, D.; Safdar, N.; Olmsted, R.N.; Saint, S. Regional Variation in Urinary Catheter Use and Catheter-Associated Urinary Tract Infection: Results from a National Collaborative. Infect. Control Hosp. Epidemiol. 2014, 35, S99-S106. [CrossRef] [PubMed]

12. Gould, C.V.; Umscheid, C.A.; Agarwal, R.K.; Kuntz, G.; Pegues, D.A.; Healthcare Infection Control Practices Advisory Committee. Guideline for prevention of catheter-associated urinary tract infections 2009. Infect. Control Hosp. Epidemiol. 2010, 31, 319-326. [CrossRef] [PubMed]

13. Meddings, J.; Saint, S.; Fowler, K.E.; Gaies, E.; Hickner, A.; Krein, S.L.; Bernstein, S.J. The Ann Arbor Criteria for Appropriate Urinary Catheter Use in Hospitalized Medical Patients: Results Obtained by Using the RAND/UCLA Appropriateness Method. Ann. Intern. Med. 2015, 162 (Suppl. 9), S1-S34. [CrossRef]

14. Munasinghe, R.L.; Yazdani, H.; Siddique, M.; Hafeez, W. Appropriateness of use of indwelling urinary catheters in patients admitted to the medical service. Infect. Control Hosp. Epidemiol. 2001, 22, 647-649. [CrossRef] [PubMed]

15. Singha, P.; Locklin, J.; Handa, H. A review of the recent advances in antimicrobial coatings for urinary catheters. Acta Biomater. 2017, 50, 20-40. [CrossRef] [PubMed]

16. Schumm, K.; Lam, T.B. Types of urethral catheters for management of short-term voiding problems in hospitalised adults. Cochrane Database Syst. Rev. 2008, CD004013. [CrossRef]

17. Lo, E.; Nicolle, L.E.; Coffin, S.E.; Gould, C.; Maragakis, L.L.; Meddings, J.; Pegues, D.A.; Pettis, A.M.; Saint, S.; Yokoe, D.S. Strategies to prevent catheter-associated urinary tract infections in acute care hospitals: 2014 update. Infect. Control Hosp. Epidemiol. 2014, 35, 464-479. [CrossRef]

18. Saint, S.; Chenoweth, C.E. Biofilms and catheter-associated urinary tract infections. Infect. Dis. Clin. N. Am. 2003, 17, 411-432. [CrossRef]

19. Durant, D.J. Nurse-driven protocols and the prevention of catheter-associated urinary tract infections: A systematic review. Am. J. Infect. Control 2017, 45, 1331-1341. [CrossRef]

20. Thomas, W.E.; Nilsson, L.M.; Forero, M.; Sokurenko, E.V.; Vogel, V. Shear-dependent 'stick-and-roll' adhesion of type 1 fimbriated Escherichia coli. Mol. Microbiol. 2004, 53, 1545-1557. [CrossRef]

21. Hooton, T.M.; Bradley, S.F.; Cardenas, D.D.; Colgan, R.; Geerlings, S.E.; Rice, J.C.; Saint, S.; Schaeffer, A.J.; Tambayh, P.A.; Tenke, P.; et al. Diagnosis, prevention, and treatment of catheter-associated urinary tract infection in adults: 2009 International Clinical Practice Guidelines from the Infectious Diseases Society of America. Clin. Infect. Dis. 2010, 50, 625-663. [CrossRef] [PubMed]

22. Tenke, P.; Koves, B.; Johansen, T.E. An update on prevention and treatment of catheter-associated urinary tract infections. Curr. Opin. Infect. Dis. 2014, 27, 102-107. [CrossRef] [PubMed]

23. Team, E.E. CDC publishes report on antibiotic resistance threats in the United States for the first time. Eurosurveillance 2013, 18, 28.

24. Ha, U.S.; Cho, Y.H. Catheter-associated urinary tract infections: New aspects of novel urinary catheters. Int. J. Antimicrob. Agents 2006, 28, 485-490. [CrossRef] [PubMed] 
25. Johnson, J.R.; Berggren, T.; Conway, A.J. Activity of a Nitrofurazone Matrix Urinary Catheter against Catheter-Associated Uropathogens. Antimicrob. Agents Chemother. 1993, 37, 2033-2036. [CrossRef]

26. Pickard, R.; Lam, T.; Maclennan, G.; Starr, K.; Kilonzo, M.; McPherson, G.; Gillies, K.; McDonald, A.; Walton, K.; Buckley, B.; et al. Types of urethral catheter for reducing symptomatic urinary tract infections in hospitalised adults requiring short-term catheterisation: Multicentre randomised controlled trial and economic evaluation of antimicrobial- and antiseptic-impregnated urethral catheters (the CATHETER trial). Health Technol. Assess. 2012, 16,1-197.

27. Lam, T.B.; Omar, M.I.; Fisher, E.; Gillies, K.; MacLennan, S. Types of indwelling urethral catheters for short-term catheterisation in hospitalised adults. Cochrane Database Syst. Rev. 2014, CD004013. [CrossRef]

28. Zhu, Z.; Wang, Z.; Li, S.; Yuan, X. Antimicrobial strategies for urinary catheters. J. Biomed. Mater. Res. A 2019, 107, 445-467. [CrossRef]

29. Ruutu, M.; Alfthan, O.; Talja, M.; Andersson, L.C. Cytotoxicity of latex urinary catheters. Br. J. Urol. 1985, 57, 82-87. [CrossRef]

30. Lawrence, E.L.; Turner, I.G. Kink, flow and retention properties of urinary catheters part 1: Conventional foley catheters. J. Mater. Sci. Mater. Med. 2006, 17, 147-152. [CrossRef]

31. Stensballe, J.; Looms, D.; Nielsen, P.N.; Tvede, M. Hydrophilic-coated catheters for intermittent catheterisation reduce urethral micro trauma: A prospective, randomised, participant-blinded, crossover study of three different types of catheters. Eur. Urol. 2005, 48, 978-983. [CrossRef] [PubMed]

32. Francolini, I.; Vuotto, C.; Piozzi, A.; Donelli, G. Antifouling and antimicrobial biomaterials: An overview. APMIS 2017, 125, 392-417. [CrossRef] [PubMed]

33. Lim, K.; Chua, R.R.; Bow, H.; Tambyah, P.A.; Hadinoto, K.; Leong, S.S. Development of a catheter functionalized by a polydopamine peptide coating with antimicrobial and antibiofilm properties. Acta Biomater. 2015, 15, 127-138. [CrossRef] [PubMed]

34. Wang, L.; Zhang, S.; Keatch, R.; Corner, G.; Nabi, G.; Murdoch, S.; Davidson, F.; Zhao, Q. In-vitro antibacterial and anti-encrustation performance of silver-polytetrafluoroethylene nanocomposite coated urinary catheters. J. Hosp. Infect. 2019, 103, 55-63. [CrossRef]

35. Kunin, C.M.; Chin, Q.F.; Chambers, S. Formation of encrustations on indwelling urinary catheters in the elderly: A comparison of different types of catheter materials in "blockers" and "nonblockers". J. Urol. 1987, 138, 899-902. [CrossRef]

36. Murakami, S.; Igarashi, T.; Tanaka, M.; Tobe, T.; Mikami, K. Adherence of bacteria to various urethral catheters and occurrence of catheter-induced urethritis. Hinyokika Kiyo 1993, 39, 107-111.

37. Kilonzo, M.; Vale, L.; Pickard, R.; Lam, T.; N’Dow, J.; Catheter Trial Group. Cost effectiveness of antimicrobial catheters for adults requiring short-term catheterisation in hospital. Eur. Urol. 2014, 66, 615-618. [CrossRef]

38. Pickard, R.; Lam, T.; MacLennan, G.; Starr, K.; Kilonzo, M.; McPherson, G.; Gillies, K.; McDonald, A.; Walton, K.; Buckley, B. Antimicrobial catheters for reduction of symptomatic urinary tract infection in adults requiring short-term catheterisation in hospital: A multicentre randomised controlled trial. Lancet 2012, 380, 1927-1935. [CrossRef]

39. Kazmierska, K.A.; Thompson, R.; Morris, N.; Long, A.; Ciach, T. In vitro multicompartmental bladder model for assessing blockage of urinary catheters: Effect of hydrogel coating on dynamics of Proteus mirabilis growth. Urology 2010, 76, 515-e15-515-e20. [CrossRef]

40. Stickler, D.J.; Evans, A.; Morris, N.; Hughes, G. Strategies for the control of catheter encrustation. Int. J. Antimicrob. Agents 2002, 19, 499-506. [CrossRef]

41. Diaz Blanco, C.; Ortner, A.; Dimitrov, R.; Navarro, A.; Mendoza, E.; Tzanov, T. Building an antifouling zwitterionic coating on urinary catheters using an enzymatically triggered bottom-up approach. ACS Appl. Mater. Interfaces 2014, 6, 11385-11393. [CrossRef] [PubMed]

42. Alcantar, N.A.; Aydil, E.S.; Israelachvili, J.N. Polyethylene glycol-coated biocompatible surfaces. J. Biomed. Mater. Res. 2000, 51, 343-351. [CrossRef]

43. Lipovsky, A.; Thallinger, B.; Perelshtein, I.; Ludwig, R.; Sygmund, C.; Nyanhongo, G.S.; Guebitz, G.M.; Gedanken, A. Ultrasound coating of polydimethylsiloxanes with antimicrobial enzymes. J. Mater. Chem. B 2015, 3, 7014-7019. [CrossRef]

44. Park, K.D.; Kim, Y.S.; Han, D.K.; Kim, Y.H.; Lee, E.H.B.; Suh, H.; Choi, K.S. Bacterial adhesion on PEG modified polyurethane surfaces. Biomaterials 1998, 19, 851-859. [CrossRef] 
45. Vaterrodt, A.; Thallinger, B.; Daumann, K.; Koch, D.; Guebitz, G.M.; Ulbricht, M. Antifouling and Antibacterial Multifunctional Polyzwitterion/Enzyme Coating on Silicone Catheter Material Prepared by Electrostatic Layer-by-Layer Assembly. Langmuir 2016, 32, 1347-1359. [CrossRef] [PubMed]

46. Yang, C.; Ding, X.; Ono, R.J.; Lee, H.; Hsu, L.Y.; Tong, Y.W.; Hedrick, J.; Yang, Y.Y. Brush-like polycarbonates containing dopamine, cations, and PEG providing a broad-spectrum, antibacterial, and antifouling surface via one-step coating. Adv. Mater. 2014, 26, 7346-7351. [CrossRef]

47. Catto, C.; Villa, F.; Cappitelli, F. Recent progress in bio-inspired biofilm-resistant polymeric surfaces. Crit. Rev. Microbiol. 2018, 44, 633-652. [CrossRef]

48. Cheng, Y.; Feng, G.; Moraru, C.I. Micro- and Nanotopography Sensitive Bacterial Attachment Mechanisms: A Review. Front. Microbiol. 2019, 10, 191. [CrossRef]

49. Hsu, L.C.; Fang, J.; Borca-Tasciuc, D.A.; Worobo, R.W.; Moraru, C.I. Effect of micro- and nanoscale topography on the adhesion of bacterial cells to solid surfaces. Appl. Environ. Microbiol. 2013, 79, 2703-2712. [CrossRef]

50. Reddy, S.T.; Chung, K.K.; McDaniel, C.J.; Darouiche, R.O.; Landman, J.; Brennan, A.B. Micropatterned surfaces for reducing the risk of catheter-associated urinary tract infection: An in vitro study on the effect of sharklet micropatterned surfaces to inhibit bacterial colonization and migration of uropathogenic Escherichia coli. J. Endourol. 2011, 25, 1547-1552. [CrossRef]

51. Alshehri, S.M.; Aldalbahi, A.; Al-Hajji, A.B.; Chaudhary, A.A.; Panhuis, M.I.; Alhokbany, N.; Ahamad, T. Development of carboxymethyl cellulose-based hydrogel and nanosilver composite as antimicrobial agents for UTI pathogens. Carbohydr. Polym. 2016, 138, 229-236. [CrossRef] [PubMed]

52. Appel, W. Chymotrypsin-Molecular and Catalytic Properties. Clin. Biochem. 1986, 19, 317-322. [CrossRef]

53. Asker, D.; Awad, T.S.; Baker, P.; Howell, P.L.; Hatton, B.D. Non-eluting, surface-bound enzymes disrupt surface attachment of bacteria by continuous biofilm polysaccharide degradation. Biomaterials 2018, 167, 168-176. [CrossRef] [PubMed]

54. Baker, P.; Hill, P.J.; Snarr, B.D.; Alnabelseya, N.; Pestrak, M.J.; Lee, M.J.; Jennings, L.K.; Tam, J.; Melnyk, R.A.; Parsek, M.R. Exopolysaccharide biosynthetic glycoside hydrolases can be utilized to disrupt and prevent Pseudomonas aeruginosa biofilms. Sci. Adv. 2016, 2, e1501632. [CrossRef]

55. Catto, C.; Secundo, F.; James, G.; Villa, F.; Cappitelli, F. alpha-Chymotrypsin Immobilized on a Low-Density Polyethylene Surface Successfully Weakens Escherichia coli Biofilm Formation. Int. J. Mol. Sci. 2018, 19, 4003. [CrossRef]

56. Ivanova, K.; Fernandes, M.M.; Mendoza, E.; Tzanov, T. Enzyme multilayer coatings inhibit Pseudomonas aeruginosa biofilm formation on urinary catheters. Appl. Microbiol. Biotechnol. 2015, 99, 4373-4385. [CrossRef]

57. Snarr, B.D.; Baker, P.; Bamford, N.C.; Sato, Y.; Liu, H.; Lehoux, M.; Gravelat, F.N.; Ostapska, H.; Baistrocchi, S.R.; Cerone, R.P. Microbial glycoside hydrolases as antibiofilm agents with cross-kingdom activity. Proc. Natl. Acad. Sci. USA 2017, 114, 7124-7129. [CrossRef]

58. Thallinger, B.; Brandauer, M.; Burger, P.; Sygmund, C.; Ludwig, R.; Ivanova, K.; Kun, J.; Scaini, D.; Burnet, M.; Tzanov, T.; et al. Cellobiose dehydrogenase functionalized urinary catheter as novel antibiofilm system. J. Biomed. Mater. Res. B Appl. Biomater. 2016, 104, 1448-1456. [CrossRef]

59. McCloskey, A.P.; Gilmore, B.F.; Laverty, G. Evolution of antimicrobial peptides to self-assembled peptides for biomaterial applications. Pathogens 2014, 3, 791-821. [CrossRef]

60. Talja, M.; Korpela, A.; Jarvi, K. Comparison of urethral reaction to full silicone, hydrogen-coated and siliconised latex catheters. Br. J. Urol. 1990, 66, 652-657. [CrossRef]

61. Chene, G.; Boulard, G.; Gachie, J.P. A controlled trial of a new material for coating urinary catheters. Agressologie 1990, 31, 499-501. [PubMed]

62. Razatos, A.; Ong, Ye.; Boulay, F.; Elbert, D.L.; Hubbell, J.A.; Sharma, M.M.; Georgiou, G. Force measurements between bacteria and poly(ethylene glycol)-coated surfaces. Langmuir 2000, 16, 9155-9158. [CrossRef]

63. Segev, G.; Bankirer, T.; Steinberg, D.; Duvdevani, M.; Shapur, N.K.; Friedman, M.; Lavy, E. Evaluation of urinary catheters coated with sustained-release varnish of chlorhexidine in mitigating biofilm formation on urinary catheters in dogs. J. Vet. Intern. Med. 2013, 27, 39-46. [CrossRef] [PubMed]

64. Flores-Mireles, A.L.; Pinkner, J.S.; Caparon, M.G.; Hultgren, S.J. EbpA vaccine antibodies block binding of Enterococcus faecalis to fibrinogen to prevent catheter-associated bladder infection in mice. Sci. Transl. Med. 2014, 6, 254ra127. [CrossRef] 
65. Flores-Mireles, A.L.; Walker, J.N.; Bauman, T.M.; Potretzke, A.M.; Schreiber, H.L.; Park, A.M.; Pinkner, J.S.; Caparon, M.G.; Hultgren, S.J.; Desai, A. Fibrinogen Release and Deposition on Urinary Catheters Placed during Urological Procedures. J. Urol. 2016, 196, 416-421. [CrossRef]

66. Guiton, P.S.; Hannan, T.J.; Ford, B.; Caparon, M.G.; Hultgren, S.J. Enterococcus faecalis overcomes foreign body-mediated inflammation to establish urinary tract infections. Infect. Immun. 2013, 81, 329-339. [CrossRef]

67. Limoli, D.H.; Jones, C.J.; Wozniak, D.J. Bacterial Extracellular Polysaccharides in Biofilm Formation and Function. Microbiol. Spectr. 2015, 3. [CrossRef]

68. Lehman, S.M.; Donlan, R.M. Bacteriophage-mediated control of a two-species biofilm formed by microorganisms causing catheter-associated urinary tract infections in an in vitro urinary catheter model. Antimicrob. Agents Chemother. 2015, 59, 1127-1137. [CrossRef]

69. Milo, S.; Hathaway, H.; Nzakizwanayo, J.; Alves, D.; Esteban, P.P.; Jones, B.V.; Jenkins, A. Prevention of encrustation and blockage of urinary catheters by Proteus mirabilis via $\mathrm{pH}$-triggered release of bacteriophage. J. Mater. Chem. B 2017, 5, 5403-5411. [CrossRef]

70. Pugach, J.L.; DiTizio, V.; Mittelman, M.W.; Bruce, A.W.; DiCosmo, F.; Khoury, A.E. Antibiotic hydrogel coated Foley catheters for prevention of urinary tract infection in a rabbit model. J. Urol. 1999, 162 Pt 1, 883-887. [CrossRef]

71. Zhang, S.; Wang, L.; Liang, X.; Vorstius, J.; Keatch, R.; Corner, G.; Nabi, G.; Davidson, F.; Gadd, G.M.; Zhao, Q. Enhanced Antibacterial and Antiadhesive Activities of Silver-PTFE Nanocomposite Coating for Urinary Catheters. ACS Biomater. Sci. Eng. 2019, 5, 2804-2814. [CrossRef]

72. Bologna, R.A.; Tu, L.M.; Polansky, M.; Fraimow, H.D.; Gordon, D.A.; Whitmore, K.E. Hydrogel/silver ion-coated urinary catheter reduces nosocomial urinary tract infection rates in intensive care unit patients: A multicenter study. Urology 1999, 54, 982-987. [CrossRef]

73. Chung, P.H.; Wong, C.W.; Lai, C.K.; Siu, H.K.; Tsang, D.N.; Yeung, K.Y.; Ip, D.K.; Tam, P.K. A prospective interventional study to examine the effect of a silver alloy and hydrogel-coated catheter on the incidence of catheter-associated urinary tract infection. Hong Kong Med. J. 2017, 23, 239-245. [CrossRef] [PubMed]

74. Desai, D.G.; Liao, K.S.; Cevallos, M.E.; Trautner, B.W. Silver or nitrofurazone impregnation of urinary catheters has a minimal effect on uropathogen adherence. J. Urol. 2010, 184, 2565-2571. [CrossRef] [PubMed]

75. Fuchs, A.V.; Ritz, S.; Pütz, S.; Mailänder, V.; Landfester, K.; Ziener, U. Bioinspired phosphorylcholine containing polymer films with silver nanoparticles combining antifouling and antibacterial properties. Biomater. Sci. 2013, 1, 470-477. [CrossRef]

76. Funao, H.; Nagai, S.; Sasaki, A.; Hoshikawa, T.; Tsuji, T.; Okada, Y.; Koyasu, S.; Toyama, Y.; Nakamura, M.; Aizawa, M.; et al. A novel hydroxyapatite film coated with ionic silver via inositol hexaphosphate chelation prevents implant-associated infection. Sci. Rep. 2016, 6, 23238. [CrossRef]

77. Johnson, J.R.; Delavari, P.; Azar, M. Activities of a nitrofurazone-containing urinary catheter and a silver hydrogel catheter against multidrug-resistant bacteria characteristic of catheter-associated urinary tract infection. Antimicrob. Agents Chemother. 1999, 43, 2990-2995. [CrossRef]

78. Karchmer, T.B.; Giannetta, E.T.; Muto, C.A.; Strain, B.A.; Farr, B.M. A randomized crossover study of silver-coated urinary catheters in hospitalized patients. Arch. Intern. Med. 2000, 160, 3294-3298. [CrossRef]

79. Kowalczuk, D.; Ginalska, G.; Piersiak, T.; Miazga-Karska, M. Prevention of biofilm formation on urinary catheters: Comparison of the sparfloxacin-treated long-term antimicrobial catheters with silver-coated ones. J. Biomed. Mater. Res. B Appl. Biomater. 2012, 100, 1874-1882. [CrossRef]

80. Lederer, J.W.; Jarvis, W.R.; Thomas, L.; Ritter, J. Multicenter cohort study to assess the impact of a silver-alloy and hydrogel-coated urinary catheter on symptomatic catheter-associated urinary tract infections. J. Wound Ostomy Continence Nurs. 2014, 41, 473-480. [CrossRef]

81. Leuck, A.M.; Johnson, J.R.; Hunt, M.A.; Dhody, K.; Kazempour, K.; Ferrieri, P.; Kline, S. Safety and efficacy of a novel silver-impregnated urinary catheter system for preventing catheter-associated bacteriuria: A pilot randomized clinical trial. Am. J. Infect. Control 2015, 43, 260-265. [CrossRef]

82. Mala, R.; Annie Aglin, A.; Ruby Celsia, A.S.; Geerthika, S.; Kiruthika, N.; VazagaPriya, C.; Srinivasa Kumar, K. Foley catheters functionalised with a synergistic combination of antibiotics and silver nanoparticles resist biofilm formation. IET Nanobiotechnol. 2017, 11, 612-620. [CrossRef] [PubMed]

83. Mandakhalikar, K.D.; Wang, R.; Rahmat, J.N.; Chiong, E.; Neoh, K.G.; Tambyah, P.A. Restriction of in vivo infection by antifouling coating on urinary catheter with controllable and sustained silver release: A proof of concept study. BMC Infect. Dis. 2018, 18, 370. [CrossRef] 
84. Ogilvie, A.T.; Brisson, B.A.; Gow, W.R.; Wainberg, S.; Singh, A.; Weese, J.S. Effects of the use of silver-coated urinary catheters on the incidence of catheter-associated bacteriuria and urinary tract infection in dogs. J. Am. Vet. Med. Assoc. 2018, 253, 1289-1293. [CrossRef]

85. Roe, D.; Karandikar, B.; Bonn-Savage, N.; Gibbins, B.; Roullet, J.B. Antimicrobial surface functionalization of plastic catheters by silver nanoparticles. J. Antimicrob. Chemother. 2008, 61, 869-876. [CrossRef]

86. Thibon, P.; Le Coutour, X.; Leroyer, R.; Fabry, J. Randomized multi-centre trial of the effects of a catheter coated with hydrogel and silver salts on the incidence of hospital-acquired urinary tract infections. J. Hosp. Infect. 2000, 45, 117-124. [CrossRef]

87. Li, X.; Li, P.; Saravanan, R.; Basu, A.; Mishra, B.; Lim, S.H.; Su, X.; Tambyah, P.A.; Leong, S.S. Antimicrobial functionalization of silicone surfaces with engineered short peptides having broad spectrum antimicrobial and salt-resistant properties. Acta Biomater. 2014, 10, 258-266. [CrossRef]

88. Mudshinge, S.R.; Deore, A.B.; Patil, S.; Bhalgat, C.M. Nanoparticles: Emerging carriers for drug delivery. Saudi Pharm. J. 2011, 19, 129-141. [CrossRef]

89. Burdusel, A.C.; Gherasim, O.; Grumezescu, A.M.; Mogoantă, L.; Ficai, A.; Andronescu, E. Biomedical Applications of Silver Nanoparticles: An Up-to-Date Overview. Nanomaterials 2018, 8, 681. [CrossRef]

90. Kedziora, A.; Speruda, M.; Krzyżewska, E.; Rybka, J.; Łukowiak, A.; Bugla-Płoskońska, G. Similarities and Differences between Silver Ions and Silver in Nanoforms as Antibacterial Agents. Int. J. Mol. Sci. 2018, 19, 444. [CrossRef]

91. Lee, S.J.; Kim, S.W.; Cho, Y.H.; Shin, W.S.; Lee, S.E.; Kim, C.S.; Hong, S.J.; Chung, B.H.; Kim, J.J.; Yoon, M.S. A comparative multicentre study on the incidence of catheter-associated urinary tract infection between nitrofurazone-coated and silicone catheters. Int. J. Antimicrob. Agents 2004, 24 (Suppl. 1), S65-S69. [CrossRef]

92. Arunachalam, K.D.; Annamalai, S.K.; Arunachalam, A.M.; Raghavendra, R.S.; Kennedy, S. One step green synthesis of phytochemicals mediated gold nanoparticles from Aegle marmales for the prevention of urinary catheter infection. Int. J. Pharm. Pharm. Sci. 2014, 6, 700-706.

93. Dizaj, S.M.; Lotfipour, F.; Barzegar-Jalali, M.; Zarrintan, M.H.; Adibkia, K. Antimicrobial activity of the metals and metal oxide nanoparticles. Mater. Sci. Eng. C Mater. Biol. Appl. 2014, 44, 278-284. [CrossRef] [PubMed]

94. Borkow, G.; Gabbay, J. Putting copper into action: Copper-impregnated products with potent biocidal activities. FASEB J. 2004, 18, 1728-1730. [CrossRef] [PubMed]

95. Agarwala, M.; Choudhury, B.; Yadav, R.N. Comparative study of antibiofilm activity of copper oxide and iron oxide nanoparticles against multidrug resistant biofilm forming uropathogens. Indian J. Microbiol. 2014, 54, 365-368. [CrossRef] [PubMed]

96. Shalom, Y.; Perelshtein, I.; Perkas, N.; Gedanken, A.; Banin, E. Catheters coated with Zn-doped CuO nanoparticles delay the onset of catheter-associated urinary tract infections. Nano Res. 2017, 10, 520-533. [CrossRef]

97. Cui, Y.; Zhao, Y.; Tian, Y.; Zhang, W.; Lu, X.; Jiang, X. The molecular mechanism of action of bactericidal gold nanoparticles on Escherichia coli. Biomaterials 2012, 33, 2327-2333. [CrossRef]

98. Ohsumi, Y.; Kitamoto, K.; Anraku, Y. Changes induced in the permeability barrier of the yeast plasma membrane by cupric ion. J. Bacteriol. 1988, 170, 2676-2682. [CrossRef]

99. Borkow, G.; Gabbay, J. Biocidal textiles can help fight nosocomial infections. Med. Hypotheses 2008, 70, 990-994. [CrossRef]

100. Rtimi, S.; Sanjines, R.; Pulgarin, C.; Kiwi, J. Quasi-Instantaneous Bacterial Inactivation on Cu-Ag Nanoparticulate 3D Catheters in the Dark and Under Light: Mechanism and Dynamics. ACS Appl. Mater. Interfaces 2016, 8, 47-55. [CrossRef]

101. Mihut, D.M.; Afshar, A.; Lackey, L.W.; Le, K.N. Antibacterial effectiveness of metallic nanoparticles deposited on water filter paper by magnetron sputtering. Surf. Coat. Technol. 2019, 368, 59-66. [CrossRef]

102. Menezes, F.G.; Correa, L.; Medina-Pestana, J.O.; Aguiar, W.F.; Camargo, L.F.A. A randomized clinical trial comparing Nitrofurazone-coated and uncoated urinary catheters in kidney transplant recipients: Results from a pilot study. Transpl. Infect. Dis. 2019, 21, e13031. [CrossRef] [PubMed]

103. Cho, Y.H.; Lee, S.J.; Lee, J.Y.; Kim, S.W.; Kwon, I.C.; Chung, S.Y.; Yoon, M.S. Prophylactic efficacy of a new gentamicin-releasing urethral catheter in short-term catheterized rabbits. BJU Int. 2001, 87, 104-109. [CrossRef] [PubMed] 
104. Cho, Y.W.; Park, J.H.; Kim, S.H.; Cho, Y.H.; Choi, J.M.; Shin, H.J.; Bae, Y.H.; Chung, H.; Jeong, S.Y.; Kwon, I.C. Gentamicin-releasing urethral catheter for short-term catheterization. J. Biomater. Sci. Polym. Ed. 2003, 14, 963-972. [CrossRef] [PubMed]

105. Park, J.H.; Cho, Y.W.; Cho, Y.H.; Choi, J.M.; Shin, H.J.; Bae, Y.H.; Chung, H.; Jeong, S.Y.; Kwon, I.C. Norfloxacin-releasing urethral catheter for long-term catheterization. J. Biomater. Sci. Polym. Ed. 2003, 14, 951-962. [CrossRef]

106. Reid, G.; Sharma, S.; Advikolanu, K.; Tieszer, C.; Martin, R.A.; Bruce, A.W. Effects of ciprofloxacin, norfloxacin, and ofloxacin on in vitro adhesion and survival of Pseudomonas aeruginosa AK1 on urinary catheters. Antimicrob. Agents Chemother. 1994, 38, 1490-1495. [CrossRef]

107. Camacho, D.P.; Gasparetto, A.; Svidzinski, T.I. The effect of chlorhexidine and gentian violet on the adherence of Candida spp. to urinary catheters. Mycopathologia 2007, 163, 261-266. [CrossRef]

108. Gaonkar, T.A.; Caraos, L.; Modak, S. Efficacy of a silicone urinary catheter impregnated with chlorhexidine and triclosan against colonization with Proteus mirabilis and other uropathogens. Infect. Control Hosp. Epidemiol. 2007, 28, 596-598. [CrossRef]

109. Gefter Shenderovich, J.; Zaks, B.; Kirmayer, D.; Lavy, E.; Steinberg, D.; Friedman, M. Chlorhexidine sustained-release varnishes for catheter coating - Dissolution kinetics and antibiofilm properties. Eur. J. Pharm. Sci. 2018, 112, 1-7. [CrossRef]

110. Mitchell, B.G.; Fasugba, O.; Cheng, A.C.; Gregory, V.; Koerner, J.; Collignon, P.; Gardner, A.; Graves, N. Chlorhexidine versus saline in reducing the risk of catheter associated urinary tract infection: A cost-effectiveness analysis. Int. J. Nurs. Stud. 2019, 97, 1-6. [CrossRef]

111. Srisang, S.; Nasongkla, N. Spray coating of foley urinary catheter by chlorhexidine-loadedpoly(epsiloncaprolactone) nanospheres: Effect of lyoprotectants, characteristics, and antibacterial activity evaluation. Pharm. Dev. Technol. 2019, 24, 402-409. [CrossRef]

112. Carey, D.E.; McNamara, P.J. The impact of triclosan on the spread of antibiotic resistance in the environment. Front. Microbiol. 2014, 5, 780. [CrossRef]

113. Petersen, R.C. Triclosan antimicrobial polymers. AIMS Mol. Sci. 2016, 3, 88-103. [CrossRef] [PubMed]

114. Hahn, F.E.; Sarre, S.G. Mechanism of action of gentamicin. J. Infect. Dis. 1969, 119, 364-369. [CrossRef] [PubMed]

115. Tangy, F.; Moukkadem, M.; Vindimian, E.; Capmau, M.L.; Le Goffic, F. Mechanism of action of gentamicin components. Characteristics of their binding to Escherichia coli ribosomes. Eur. J. Biochem. 1985, 147, 381-386. [CrossRef] [PubMed]

116. Krause, K.M.; Serio, A.W.; Kane, T.R.; Connolly, L.E. Aminoglycosides: An Overview. Cold Spring Harb. Perspect. Med. 2016, 6, a027029. [CrossRef]

117. Rafienia, M.; Zarinmehr, B.; Poursamar, S.A.; Bonakdar, S.; Ghavami, M.; Janmaleki, M. Coated urinary catheter by PEG/PVA/gentamicin with drug delivery capability against hospital infection. Iran. Polym. J. 2013, 22, 75-83. [CrossRef]

118. Mohr, K.I. History of Antibiotics Research. Curr. Top. Microbiol. Immunol. 2016, 398, 237-272.

119. Collin, F.; Karkare, S.; Maxwell, A. Exploiting bacterial DNA gyrase as a drug target: Current state and perspectives. Appl. Microbiol. Biotechnol. 2011, 92, 479-497. [CrossRef]

120. Saini, H.; Chhibber, S.; Harjai, K. Antimicrobial and antifouling efficacy of urinary catheters impregnated with a combination of macrolide and fluoroquinolone antibiotics against Pseudomonas aeruginosa. Biofouling 2016, 32, 511-522. [CrossRef]

121. Russell, A.D. Whither triclosan? J. Antimicrob. Chemother. 2004, 53, 693-695. [CrossRef] [PubMed]

122. Westfall, C.; Flores-Mireles, A.L.; Robinson, J.I.; Lynch AJ, L.; Hultgren, S.; Henderson, J.P.; Levin, P.A. The Widely Used Antimicrobial Triclosan Induces High Levels of Antibiotic Tolerance In Vitro and Reduces Antibiotic Efficacy up to 100-Fold In Vivo. Antimicrob. Agents Chemother. 2019, 63, e02312-e02318. [CrossRef] [PubMed]

123. FDA. Safety and Effectiveness of Health Care Antiseptics; Topical Antimicrobial Drug Products for Over-the-Counter Human Use; Food and Drug Administration, Ed.; Federal Register: Washington, DC, USA, 2017; pp. 60474-60503.

124. McDonnell, G.; Russell, A.D. Antiseptics and disinfectants: Activity, action, and resistance. Clin. Microbiol. Rev. 1999, 12, 147-179. [CrossRef] [PubMed] 
125. Flores-Mireles, A.; Hreha, T.N.; Hunstad, D.A. Pathophysiology, Treatment, and Prevention of Catheter-Associated Urinary Tract Infection. Top. Spinal Cord Inj. Rehabil. 2019, 25, 228-240. [CrossRef] [PubMed]

126. Stewart, P.S. Mechanisms of antibiotic resistance in bacterial biofilms. Int. J. Med. Microbiol. 2002, 292, 107-113. [CrossRef] [PubMed]

127. Singh, S.; Singh, S.K.; Chowdhury, I.; Singh, R. Understanding the Mechanism of Bacterial Biofilms Resistance to Antimicrobial Agents. Open Microbiol. J. 2017, 11, 53-62. [CrossRef] [PubMed]

128. Carlsson, S.; Weitzberg, E.; Wiklund, P.; Lundberg, J.O. Intravesical nitric oxide delivery for prevention of catheter-associated urinary tract infections. Antimicrob. Agents Chemother. 2005, 49, 2352-2355. [CrossRef]

129. Regev-Shoshani, G.; Ko, M.; Miller, C.; Av-Gay, Y. Slow release of nitric oxide from charged catheters and its effect on biofilm formation by Escherichia coli. Antimicrob. Agents Chemother. 2010, 54, 273-279. [CrossRef]

130. Schairer, D.O.; Chouake, J.S.; Nosanchuk, J.D.; Friedman, A.J. The potential of nitric oxide releasing therapies as antimicrobial agents. Virulence 2012, 3, 271-279. [CrossRef]

131. Yasir, M.; Dutta, D.; Willcox, M.D.P. Comparative mode of action of the antimicrobial peptide melimine and its derivative Mel4 against Pseudomonas aeruginosa. Sci. Rep. 2019, 9, 7063. [CrossRef]

132. Strempel, N.; Strehmel, J.; Overhage, J. Potential application of antimicrobial peptides in the treatment of bacterial biofilm infections. Curr. Pharm. Des. 2015, 21, 67-84. [CrossRef] [PubMed]

133. Monteiro, C.; Costa, F.; Pirttila, A.M.; Tejesvi, M.V.; Martins, M.C.L. Prevention of urinary catheter-associated infections by coating antimicrobial peptides from crowberry endophytes. Sci. Rep. 2019, 9, 10753. [CrossRef] [PubMed]

134. Yu, K.; Lo, J.C.; Yan, M.; Yang, X.; Brooks, D.E.; Hancock, R.E.; Lange, D.; Kizhakkedathu, J.N. Anti-adhesive antimicrobial peptide coating prevents catheter associated infection in a mouse urinary infection model. Biomaterials 2017, 116, 69-81. [CrossRef] [PubMed]

135. Carson, L.; Gorman, S.P.; Gilmore, B.F. The use of lytic bacteriophages in the prevention and eradication of biofilms of Proteus mirabilis and Escherichia coli. FEMS Immunol. Med. Microbiol. 2010, 59, 447-455. [CrossRef] [PubMed]

136. Curtin, J.J.; Donlan, R.M. Using bacteriophages to reduce formation of catheter-associated biofilms by Staphylococcus epidermidis. Antimicrob. Agents Chemother. 2006, 50, 1268-1275. [CrossRef]

137. Fu, W.L.; Forster, T.; Mayer, O.; Curtin, J.J.; Lehman, S.M.; Donlan, R.M. Bacteriophage Cocktail for the Prevention of Biofilm Formation by Pseudomonas aeruginosa on Catheters in an In Vitro Model System. Antimicrob. Agents Chemother. 2010, 54, 397-404. [CrossRef]

138. Anjum, S.; Singh, S.; Benedicte, L.; Roger, P.; Panigrahi, M.; Gupta, B. Biomodification Strategies for the Development of Antimicrobial Urinary Catheters: Overview and Advances. Glob. Chall. 2018, 2, 1700068. [CrossRef]

139. Mathur, S.; Udgire, M.; Khambhapati, A.; Paul, D. Anti-biofilm activity and bioactive component analysis of eucalyptus oil against urinary tract pathogen. Int. J. Curr. Microbiol. Appl. Sci. 2014, 3, 912-918.

140. Karpanen, T.J.; Worthington, T.; Hendry, E.R.; Conway, B.R.; Lambert, P.A. Antimicrobial efficacy of chlorhexidine digluconate alone and in combination with eucalyptus oil, tea tree oil and thymol against planktonic and biofilm cultures of Staphylococcus epidermidis. J. Antimicrob. Chemother. 2008, 62, 1031-1036. [CrossRef]

141. Chifiriuc, C.; Grumezescu, V.; Grumezescu, A.M.; Saviuc, C.; Lazar, V.; Andronescu, E. Hybrid magnetite nanoparticles/Rosmarinus officinalis essential oil nanobiosystem with antibiofilm activity. Nanoscale Res. Lett. 2012, 7, 209. [CrossRef]

142. Malic, S.; Jordan, R.P.; Waters, M.G.; Stickler, D.J.; Williams, D.W. Biocide activity against urinary catheter pathogens. Antimicrob. Agents Chemother. 2014, 58, 1192-1194. [CrossRef] [PubMed]

143. Nowatzki, P.J.; Koepsel, R.R.; Stoodley, P.; Min, K.; Harper, A.; Murata, H.; Donfack, J.; Hortelano, E.R.; Ehrlich, G.D.; Russell, A.J. Salicylic acid-releasing polyurethane acrylate polymers as anti-biofilm urological catheter coatings. Acta Biomater. 2012, 8, 1869-1880. [CrossRef] [PubMed]

144. Muller, E.; Al-Attar, J.; Wolff, A.G.; Farber, B.F. Mechanism of salicylate-mediated inhibition of biofilm in Staphylococcus epidermidis. J. Infect. Dis. 1998, 177, 501-503. [CrossRef] [PubMed]

145. Komnatnyy, V.V.; Chiang, W.C.; Tolker-Nielsen, T.; Givskov, M.; Nielsen, T.E. Bacteria-triggered release of antimicrobial agents. Angew. Chem. Int. Ed. Engl. 2014, 53, 439-441. [CrossRef] [PubMed] 
146. Zhou, J.; Hou, S.; Li, L.; Yao, D.; Liu, Y.; Jenkins AT, A.; Fan, Y. Theranostic Infection-Responsive Coating to In Situ Detect and Prevent Urinary Catheter Blockage. Adv. Mater. 2018, 5. [CrossRef]

147. Darouiche, R.O;; Hull, R.A. Bacterial interference for prevention of urinary tract infection. Clin. Infect. Dis. 2012, 55, 1400-1407. [CrossRef]

148. Prasad, A.; Cevallos, M.E.; Riosa, S.; Darouiche, R.O.; Trautner, B.W. A bacterial interference strategy for prevention of UTI in persons practicing intermittent catheterization. Spinal Cord 2009, 47, 565-569. [CrossRef]

149. Horwitz, D.; McCue, T.; Mapes, A.C.; Ajami, N.J.; Petrosino, J.F.; Ramig, R.F.; Trautner, B.W. Decreased microbiota diversity associated with urinary tract infection in a trial of bacterial interference. J. Infect. 2015, 71, 358-367. [CrossRef]

150. Flores-Mireles, A.L.; Walker, J.N.; Potretzke, A.; Schreiber, H.L.T.; Pinkner, J.S.; Bauman, T.M.; Park, A.M.; Desai, A.; Hultgren, S.J.; Caparon, M.G. Antibody-Based Therapy for Enterococcal Catheter-Associated Urinary Tract Infections. mBio 2016, 7. [CrossRef]

151. Dayyoub, E.; Frant, M.; Pinnapireddy, S.R.; Liefeith, K.; Bakowsky, U. Antibacterial and anti-encrustation biodegradable polymer coating for urinary catheter. Int. J. Pharm. 2017, 531, 205-214. [CrossRef]

152. Gaonkar, T.A.; Sampath, L.A.; Modak, S.M. Evaluation of the antimicrobial efficacy of urinary catheters impregnated with antiseptics in an in vitro urinary tract model. Infect. Control Hosp. Epidemiol. 2003, 24, 506-513. [CrossRef]

153. Aflori, M.; Miron, C.; Dobromir, M.; Drobota, M. Bactericidal effect on Foley catheters obtained by plasma and silver nitrate treatments. High Perform. Polym. 2015, 27, 655-660. [CrossRef]

154. Maisetta, G.; Grassi, L.; Di Luca, M.; Bombardelli, S.; Medici, C.; Brancatisano, F.L. Anti-biofilm properties of the antimicrobial peptide temporin $1 \mathrm{~Tb}$ and its ability, in combination with EDTA, to eradicate Staphylococcus epidermidis biofilms on silicone catheters. Biofouling 2016, 32, 787-800. [CrossRef]

155. Liao, K.S.; Lehman, S.M.; Tweardy, D.J.; Donlan, R.M.; Trautner, B.W. Bacteriophages are synergistic with bacterial interference for the prevention of Pseudomonas aeruginosa biofilm formation on urinary catheters. J. Appl. Microbiol. 2012, 113, 1530-1539. [CrossRef]

156. Xu, W.; Flores-Mireles, A.L.; Cusumano, Z.T.; Takagi, E.; Hultgren, S.J.; Caparon, M.G. Host and bacterial proteases influence biofilm formation and virulence in a murine model of enterococcal catheter-associated urinary tract infection. NPJ Biofilms Microbiomes 2017, 3, 28. [CrossRef]

157. Colomer-Winter, C.; Lemos, J.A.; Flores-Mireles, A.L. Biofilm Assays on Fibrinogen-coated Silicone Catheters and 96-well Polystyrene Plates. Bio Protoc. 2019, 9, e3196. [CrossRef]

158. Conover, M.S.; Hadjifrangiskou, M.; Palermo, J.J.; Hibbing, M.E.; Dodson, K.W.; Hultgren, S.J. Metabolic Requirements of Escherichia coli in Intracellular Bacterial Communities during Urinary Tract Infection Pathogenesis. mBio 2016, 7, e00104-e00116. [CrossRef]

159. Armbruster, C.E.; Forsyth-DeOrnellas, V.; Johnson, A.O.; Smith, S.N.; Zhao, L.; Wu, W.; Mobley, H.L.T. Genome-wide transposon mutagenesis of Proteus mirabilis: Essential genes, fitness factors for catheter-associated urinary tract infection, and the impact of polymicrobial infection on fitness requirements. PLoS Pathog. 2017, 13, e1006434. [CrossRef]

160. Klumpp, S.; Hwa, T. Bacterial growth: Global effects on gene expression, growth feedback and proteome partition. Curr. Opin. Biotechnol. 2014, 28, 96-102. [CrossRef]

161. Beebout, C.J.; Eberly, A.R.; Werby, S.H.; Reasoner, S.A.; Brannon, J.R.; De, S.; Fitzgerald, M.J.; Huggins, M.M.; Clayton, D.B.; Cegelski, L.; et al. Respiratory Heterogeneity Shapes Biofilm Formation and Host Colonization in Uropathogenic Escherichia coli. mBio 2019, 10, e02400-e02418. [CrossRef]

162. Giannakopoulos, X.; Evangelou, A.; Kalfakakou, V.; Grammeniatis, E.; Papandropoulos, I.; Charalambopoulos, K. Human bladder urine oxygen content: Implications for urinary tract diseases. Int. Urol. Nephrol. 1997, 29, 393-401. [CrossRef] [PubMed]

163. Goble, N.M.; Clarke, T.; Hammonds, J.C. Histological changes in the urinary bladder secondary to urethral catheterisation. Br. J. Urol. 1989, 63, 354-357. [CrossRef] [PubMed]

164. Glahn, B.E.; Braendstrup, O.; Olesen, H.P. Influence of drainage conditions on mucosal bladder damage by indwelling catheters. II. Histological study. Scand. J. Urol. Nephrol. 1988, 22, 93-99. [CrossRef] [PubMed]

165. Peychl, L.; Zalud, R. Changes in the urinary bladder caused by short-term permanent catheter insertion. Cas. Lek. Cesk. 2008, 147, 325-329. [PubMed]

166. Flores-Mireles, A.L.; Walker, J.N.; Caparon, M.; Hultgren, S.J. Urinary tract infections: Epidemiology, mechanisms of infection and treatment options. Nat. Rev. Microbiol. 2015, 13, 269-284. [CrossRef] [PubMed] 
167. Walker, J.N.; Flores-Mireles, A.L.; Pinkner, C.L.; Schreiber, H.L.T.; Joens, M.S.; Park, A.M.; Potretzke, A.M.; Bauman, T.M.; Pinkner, J.S.; Fitzpatrick, J.A.J. Catheterization alters bladder ecology to potentiate Staphylococcus aureus infection of the urinary tract. Proc. Natl. Acad. Sci. USA 2017, 114, E8721-E8730. [CrossRef] [PubMed]

168. Di Venanzio, G.; Flores-Mireles, A.L.; Calix, J.J.; Haurat, M.F.; Scott, N.E.; Palmer, L.D.; Potter, R.F.; Hibbing, M.E.; Friedman, L.; Wang, B. Urinary tract colonization is enhanced by a plasmid that regulates uropathogenic Acinetobacter baumannii chromosomal genes. Nat. Commun. 2019, 10, 2763. [CrossRef]

(C) 2019 by the authors. Licensee MDPI, Basel, Switzerland. This article is an open access article distributed under the terms and conditions of the Creative Commons Attribution (CC BY) license (http://creativecommons.org/licenses/by/4.0/). 